This report was prepared as an account of work sponsored by an agency of the United States Government. Neither the United States Government nor any agency thereof, nor any of their employees, makes any warranty, express or implied, or assumes any legal liability or responsibility for the accuracy, completeness, or usefulness of any information, apparatus, product, or process disclosed, or represents that its use would not infringe privately owned rights. Reference herein to any specific commercial product, process, or service by trade name, trademark, manufacturer, or otherwise does not necessarily constitute or imply its endorsement, recommendation, or favoring by the United States Government or any agency thereof. The views and opinions of authors expressed herein do not necessarily state or reflect those of the United States Government or any agency thereof.

Energy Systems Environmental Restoration Program

\title{
The Subsurface Hydrology Around Building 9201-2: Results of the July 1994 Water Level Recovery Test, Oak Ridge Y-12 Plant, Oak Ridge, Tennessee
}

Date Issued-June 1996

\author{
Prepared by \\ Environmental Sciences Division \\ Oak Ridge National Laboratory \\ P.O. Box 2008 \\ Oak Ridge, Tennessee 37831-6036
}

\author{
Prepared for the \\ U.S. Department of Energy \\ Office of Environmental Management \\ under budget and reporting code EW 20
}

Environmental Management Activities at the

OAK RIDGE Y-12 PLANT

Oak Ridge, Tennessee 37831-8169

managed by

LOCKHEED MARTIN ENERGY SYSTEMS, INC.

for the

U.S. DEPARTMENT OF ENERGY

under contract DE-AC05-84OR21400 


\section{DISCLAIMER}

Portions of this document may be illegible in electronic image products. Images are produced from the best available original document. 


\section{PREFACE}

The study described in The Subsurface Hydrology Around Building 9201-2: Results of the July 1994 Water Level Recovery Test was performed under work breakdown structure 1.1.03.44.05.10.10 (ADS 2303, "Upper East Fork Poplar Creek"). This document describes the efforts and results of a water level recovery test at the Y-12 Plant, describes the geohydrology around Bldg. 9201-2 at the Y-12 Plant, and makes recommendations for improving sump operation in the basement of Bldg. 9201-2. 


\section{CONTENTS}

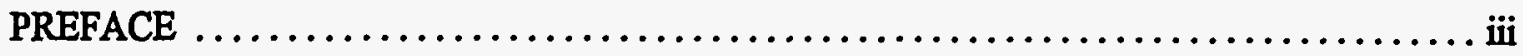

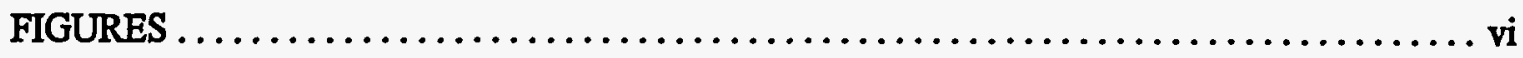

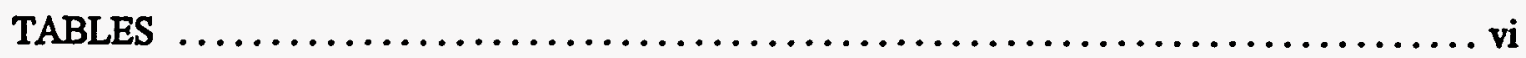

EXECUTIVE SUMMARY $\ldots \ldots \ldots \ldots \ldots \ldots \ldots \ldots \ldots \ldots \ldots \ldots \ldots \ldots \ldots \ldots \ldots \ldots$

1. INTRODUCTION $\ldots \ldots \ldots \ldots \ldots \ldots \ldots \ldots \ldots \ldots \ldots \ldots \ldots \ldots \ldots \ldots \ldots \ldots \ldots \ldots \ldots$

1.1 HISTORICAL BACKGROUND $\ldots \ldots \ldots \ldots \ldots \ldots \ldots \ldots \ldots \ldots \ldots \ldots \ldots \ldots \ldots$

1.2 PURPOSE OF WATER LEVEL RECOVERY TEST $\ldots \ldots \ldots \ldots \ldots \ldots \ldots \ldots \ldots 1$

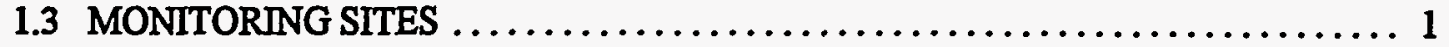

1.4 GENERAL GEOLOGY OF AREA AROUND BLDG. $9201-2 \ldots \ldots \ldots \ldots \ldots \ldots 1$

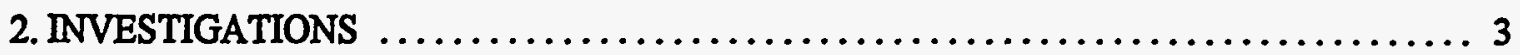

2.1 ACTIVITIES BEFORE THE WATER LEVEL RECOVERY TEST $\ldots \ldots \ldots \ldots \ldots \ldots 3$

2.2 ACTIVITIES DURING THE WATER LEVEL RECOVERY TEST $\ldots \ldots \ldots \ldots \ldots 9$

2.3 REVIEW OF DATA QUALITY $\ldots \ldots \ldots \ldots \ldots \ldots \ldots \ldots \ldots \ldots \ldots \ldots \ldots \ldots \ldots$

3. RESULTS AND CONCLUSIONS $\ldots \ldots \ldots \ldots \ldots \ldots \ldots \ldots \ldots \ldots \ldots \ldots \ldots \ldots \ldots \ldots \ldots \ldots \ldots$

3.1 SUMP $0-12$ AND PIEZOMETERS $\ldots \ldots \ldots \ldots \ldots \ldots \ldots \ldots \ldots \ldots \ldots \ldots \ldots \ldots \ldots$

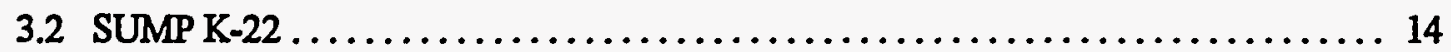

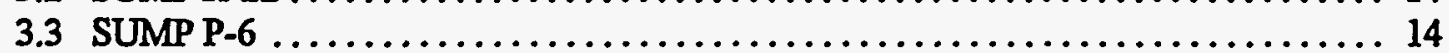

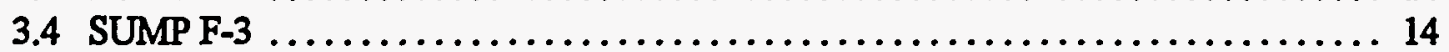

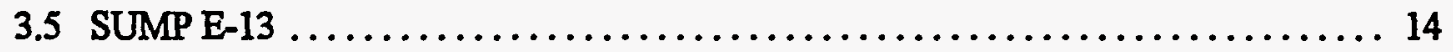

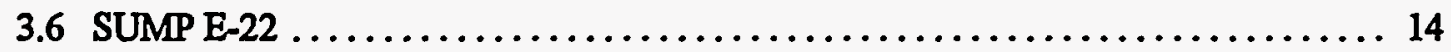

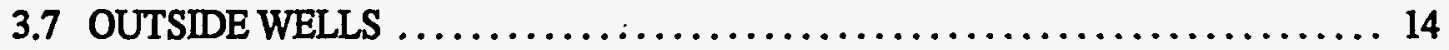

3.8 OVERVIEW OF SUBSURFACE HYDROLOGY OF THE AREA $\ldots \ldots \ldots \ldots \ldots 17$

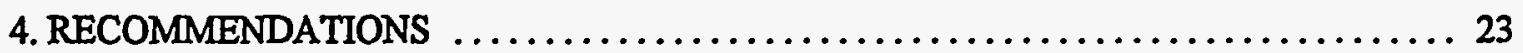

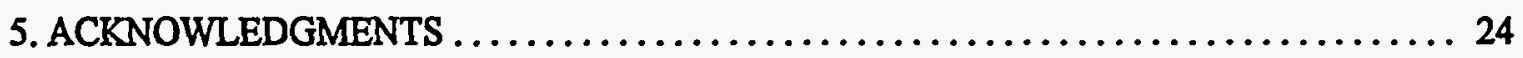

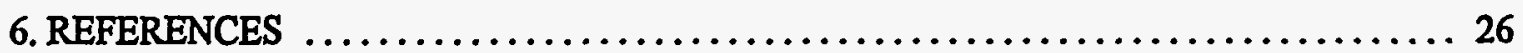

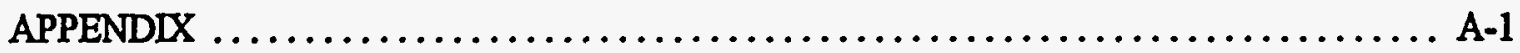




\section{FIGURES}

1.1. Map of well, piezometer, and sump locations $\ldots \ldots \ldots \ldots \ldots \ldots \ldots \ldots \ldots \ldots \ldots \ldots \ldots \ldots$

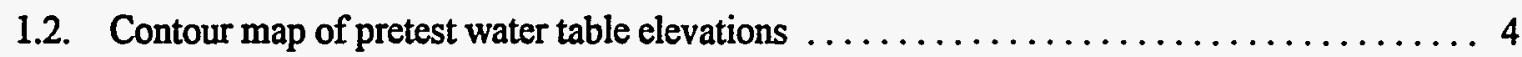

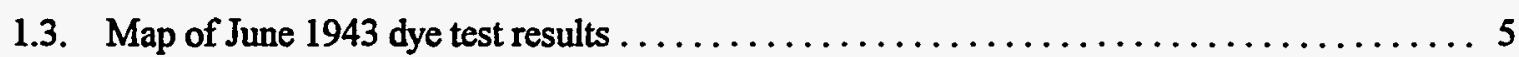

2.1. Water level changes in wells $60-1 \mathrm{~A}, 60-2 \mathrm{~A}, \mathrm{GW}-819$ and $\mathrm{GW}-820 \ldots \ldots \ldots \ldots$

3.1. Contour map of post-test water table elevations $\ldots \ldots \ldots \ldots \ldots \ldots \ldots \ldots \ldots \ldots \ldots$

3.2. Water level changes in selected wells, sumps and the $\mathrm{K}-22$ pit $\ldots \ldots \ldots \ldots \ldots \ldots$

3.3. Water level changes in Sump E-13 and wells GW-819 and GW-820 .......... 16

3.4. Water level changes in Sump E-22 and wells $60-1 \mathrm{~A}$ and $60-1 \mathrm{~B} \ldots \ldots \ldots \ldots \ldots \ldots$

3.5. General groundwater flow directions around Bldg. $9201-2 \ldots \ldots \ldots \ldots \ldots \ldots$

3.6. Water level changes in Sump $0-12$ and associated piezometers $\ldots \ldots \ldots \ldots \ldots \ldots 21$

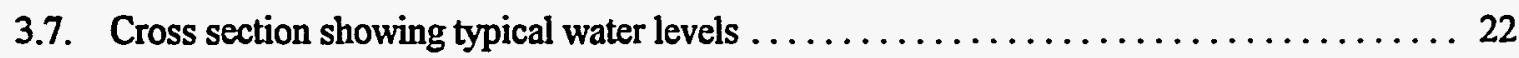

4.1. Map showing locations of new and proposed piezometers $\ldots \ldots \ldots \ldots \ldots \ldots \ldots$

\section{TABLES}

2.1 Elevation and screened interval data for wells, piezometers, and sumps $\ldots \ldots \ldots \ldots \ldots 6$

2.2 Distances between $0-12$ sump and the four $0-12$ piezometers $\ldots \ldots \ldots \ldots \ldots \ldots$

3.1 Gallons of water pumped from 0-12 sump during first $9.5 \mathrm{hr}$ after the end of the test 


\section{EXECUTIVE SUMMARY}

A water level recovery test was conducted at Bldg. 9201-2 at the Oak Ridge Y-12 Plant in Oak Ridge, Tennessee, from 12:45 p.m. on July 29 until 8:22 a.m. on July 31, 1994. The purpose of the test was to improve the general understanding of the subsurface hydrology around the building. The information is needed to determine the minimum pumping capacity necessary to maintain safe water levels in the basement of the building and to assist in designing systems for treating mercury-bearing waters in the basement.

The test was initiated by shutting off the three main sump pumps in Bldg. $9201-2$ (i.e., 0-12, E-13, and E-22) for $43.5 \mathrm{hr}$ and allowing the water in the basement to approach a static level. The pumps in sumps F-3 and P-6 were also not operating during the test. During the test, water levels were monitored in 5 sumps (P-6, O-12, F-3, E-13, and E-22); a pit near sump K-22; 4 monitoring wells or piezometers in the basement near the 0-12 sump, and 16 wells outside of the building. Sump K-22 was dry during the entire test.

Using pretest data, a large trough was identified in the water table underlying Bldg. 9201-2. Sumps $0-12, E-13$, and E-22 are located in the trough. The trough is preferentially elongated in a northwestsoutheast direction from plant grid north (plant grid north is approximately $34^{\circ}$ west of true north). The trough includes an area from the 0-12 sump to the southeast corner of the building. The shape and orientation of the trough largely correspond to the topography of the basement and also may be significantly influenced by the presence of permeable fill material in the southeast corner of the building. Other factors that may be affecting the shape and orientation of the trough include: possible discharges into the basement from an old spring near the southeast corner of the building, the presence of any permeable gaps in the concrete walls of the building, any old subsurface drains in the basement, a small hill and higher water table to the north of the building, cavities and large fractures in the Maynardville Limestone on the south side of the basement, and the water level in the Upper East Fork Poplar Creek (UEFPC).

The trough includes a cone of depression in the water table that surrounds the 0-12 sump. The size of the cone is controlled by the pumping rate of the sump. Available data suggest that the cone is partially elliptical with its major axis having an east-west orientation from plant north, which would approximately parallel the bedding planes of the bedrock.

Groundwater flow on the western side of the basement of the building both before and during the test is probably prominently eastward with some possible flow to the north and south. The flow is believed to be largely controlled by the east-west orientation of the bedding planes in the Maynardville Limestone and other bedrock.

The groundwater flow on the eastern side of the building is more complex, especially to the southeast. Permeable fill material, old channel sediments from the UEFPC, and cavities and large fractures in the Maynardville Limestone occur on the southeast corner of the building, which could provide abundant conduits for groundwater to move into the basement and eventually into the 0-12 sump. Water may also be entering the basement from the high ground to the north of Bldg. 9201-2. When the 0-12 sump was shut off, water levels in the sump and its associated four piezometers quickly equilibrated (i.e., filled in the cone of depression). However, the rest of the trough persisted throughout the test. 
The old spring is located roughly between wells GW-818 and GW-819. The spring is probably still active and may be releasing water into the basement, as well as to UEFPC through Outfall 51. The exact source (recharge area) of the spring water is unknown. However, numerous fractures and cavities in the Maynardville Limestone, in which the spring is located, may provide extensive conduits for groundwater to recharge the spring.

A persistent "mound" of water exists around wells GW-819 and 60-2A that is generally 1 to $2 \mathrm{ft}$ higher than UEFPC near Outfall 51 and the water levels in wells $60-1 \mathrm{~A}^{3}$ and $60-1 \mathrm{~B}$. This mound may be associated with the spring and would tend to prevent the movement of creek water near Outfall 51 directly northward into the basement of the building. However, the creek levels around Gauging Station 8 (UEFPC) near the southwest corner of the building, water table elevations in the monitoring wells on the south and west sides of the building, and the common occurrence of fractures and cavities in the Maynardville Limestone suggest that it is possible for some creek water to move into the subsurface and enter the basement on the southwest side of the building.

On the basis of the results of this study, the following recommendations may be made:

- Except during months when intense and/or high-volume rainfall is likely (winter and early spring) and as long as the mercury concentration in the water does not significantly increase above current levels and remain high, the water level in the 0-12 sump could be allowed to stabilize at $913 \mathrm{ft}$ above mean sea level or approximately 1 to $1.5 \mathrm{ft}$ above current typical levels. This water level would largely eliminate the cone of depression around the 0-12 sump and should significantly reduce the large volume of water that is being pumped from this sump and treated for mercury.

- The water level in E-22 could be allowed to stabilize at $915.8 \mathrm{ft}$ above mean sea level or about 5 in above the current typical water level elevation. As with the 0-12 sump, the higher water level should not threaten any equipment. The volume of water being pumped by the E- 22 sump is insignificant when compared with the $0-12$ sump.

- Low mercury water from sump E-13 should not be allowed to flow to sump 0-12 and become contaminated with mercury. Unless other contaminants are present in the water, such as radionuclides or volatile organic compounds, the water in the E-13 sump could continue to be pumped, as necessary, directly through Outfall 55 and to the creek. The excavated channel, which presently allows drainage from the E-13 area to $0-12$, should be blocked.

- If additional information is desired on the subsurface hydrology of the area around Bldg. 92012 , the installation of approximately seven more piezometers is recommended. 


\section{INTRODUCTION}

\subsection{HISTORICAL BACKGROUND}

Building 9201-2 at the Y-12 Plant in Oak Ridge, Tennessee, was constructed in 1943 to house calutrons for the electromagnetic separation of uranium. During the 1950 s and early 1960 s, elemental mercury was used in Bldg. 9201-2 and several other buildings at Y-12 to separate lithium isotopes for the manufacture of nuclear weapons. Approximately $100,000 \mathrm{lb}$ of this mercury was lost in Bldg. 9201-2 through spills and leaks (Rothschild et al. 1984; Lanning 1993). Subsequently, the unrecovered mercury contaminated soils and groundwater in the dirt floor of the basement of the building.

\subsection{PURPOSE OF WATER LEVEL RECOVERY TEST}

The purpose of the water level recovery test was to improve the understanding of the water table configuration surrounding Bldg. 9201-2 (King 1994). Information on the water table configuration is needed to determine the minimum pumping capacity necessary to maintain safe water levels in the basement of Bldg. 9201-2 and to assist in designing an adequate mercury treatment system for recovered groundwater before they are discharged into the UEFPC. Concrete-lined sumps have been installed in several areas of the basement to collect groundwater to maintain safe water levels.

\subsection{MONITORING SITES}

The monitoring sites for the water level recovery test included six sumps ( $\mathrm{P}-6, \mathrm{O}-12, \mathrm{~K}-22, \mathrm{~F}-3$, E-13, and E-22) and four piezometers near the 0-12 sump (012-1, 012-2, 012-3, and 012-4) in the basement of Bldg. 9201-2. In addition, an open pit with possible groundwater exists about $15 \mathrm{ft}$ to the east of sump K-22. The outside of the building is surrounded by 16 wells (Fig. 1.1).

Sump K-22 is typically dry, but is connected to Outfall 49 . Sump F-3 is connected to Outfall 63 , while the other sumps (i.e., P-6, O-12, E-13, and E-22) currently discharge their water through Outfall 55 (Fig. 1.1). Outfalls 49, 55, and 63 discharge directly into UEFPC. Sump E-22 has been routed to the O-12 sump. Since the water in sumps E-22 and O-12 are usually contaminated with mercury, their water is treated before being discharged through Outfall 55 .

\subsection{GENERAL GEOLOGY OF AREA AROUND BLDG. 9201-2}

The Y-12 Plant is located in Bear Creek Valley, which is bounded by Pine Ridge to the north and Chestnut Ridge to the south (Rothschild et al. 1984). The Middle and Upper Cambrian Conasauga Group outcrops in the valley and includes, from oldest to youngest, the Pumpkin Valley, Rutledge, Rogersville, Maryville (also known as the Dismal Gap), Nolichucky, and Maynardville Formations (Rothschild et al. 1984; Solomon et al. 1992). However, only the Upper Cambrian Maynardville Limestone and Nolichucky Shale outcrop in the immediate vicinity of Bldg. 9201-2. 


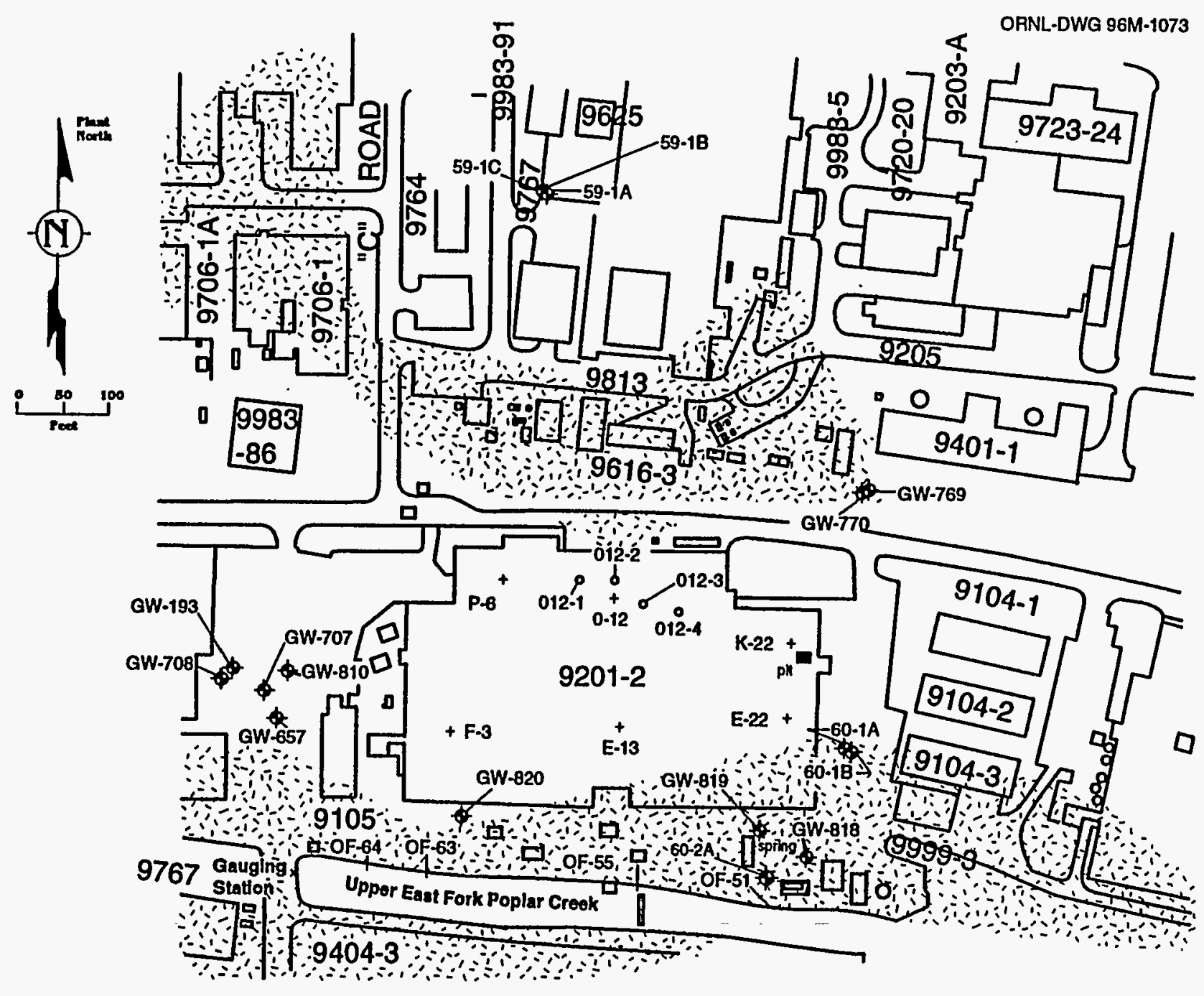

Fig. 1.1. Location of the 16 monitoring wells outside of Bldg. $9201-2$ and the six sumps, the pit near sump K-22 and the four 0-12 piezometers in the basement of the building. The shaded areas show the known locations of anthropogenic fill materials based on field observations by the authors and information in Sutton and Field (1995). Plant grid north, which is used in this figure, is approximately $34^{\circ}$ west of true north. 
Drill core and excavation data from 1943 construction diagrams and Jones et al. (1992) indicate that the contact between the Maynardville Limestone and Nolichucky Shale passes through the study area. The contact is gradual over an interval of about $15 \mathrm{ft}$ (Rothschild et al. 1984). Wells 59-1A, 59-1B, and 59-1C, which are shown in Fig. 1.1, are located in the Nolichucky Shale (Jones et al. 1992). Outcrops of the Maynardville Limestone occur in the southern portion of the basement of Bldg. 9201-2 (Fig. 1.2).

The Maynardville Limestone and Nolichucky Shale dip steeply to the southeast (based on true north) at about $30-40^{\circ}$, and their bedding planes have an average strike of about N55 $\mathrm{E}$ from true north or nearly straight east and west based on plant grid north (Solomon et al. 1992; HSW Environmental Consultants, Inc. 1994). The Maynardville Limestone is typically 125 to $145 \mathrm{~m}$ thick and consists of massive limestones and dolostones (Solomon et al. 1992; Geraghty and Miller, Inc. 1985). A red to yellowish brown clay or saprolite (weathered shale) partly covers the Maynardville Limestone and some of the northern portion of the basement (Fig. 1.2). The Nolichucky is 100 to $150 \mathrm{~m}$ thick and consists of shales with some limestones (Solomon et al. 1992; Geraghty and Miller, Inc. 1985).

Approximately $20 \mathrm{ft}$ south of sump 0-12, a very sharp contact on the surface of the basement floor occurs between the carbonates of the Maynardville Formation and the red to yellowish brown saprolite (Fig. 1.2). A fissile and perhaps largely unweathered gray shale (Nolichucky?) occurs underneath the saprolite near piezometer 012-4 and in other areas of the basement to the north of sump 0-12. Concrete or carbonates may also exist under the saprolite at piezometer 012-3. Specifically, a light-colored, very hard surface (either carbonate or concrete) was encountered during the hand drilling of the hole for piezometer 012-3.

During the construction of Bldg. 9201-2, the channel of UEFPC on the southeast side of the building was rerouted (Sutton and Field 1995). Extensive anthropogenic fill material also occurs around the building, and especially on the southeast corner and north side (Sutton and Field 1995; Rothschild et al. 1984; Fig. 1.1). The fill material and old channel sediments, along with the fractures and cavities in the Maynardville Limestone, are potentially important conduits for groundwater recharge to the sumps in the basement of Bldg. 9201-2.

A dye test conducted in June 1943 during the construction of the building indicated that the groundwater flow on the west side of the building was prominently eastward, at least at that time. Specifically, the dye was injected into borehole 39-B, which was located to the west of the site of the current building (Fig. 1.3). The dye was detected sometime later in eight other boreholes to the northeast, east, and south-southeast (based on Y-12 Plant north) of borehole 39-B.

\section{INVESTIGATIONS}

\subsection{ACTIVITIES BEFORE THE WATER LEVEL RECOVERY TEST}

Frequent monitoring of the water levels in the 16 wells surrounding Bldg. 9201-2 began on June 23,1994 . The locations of the wells are shown in Fig. 1.1; their top of casing (TOC) elevations and known screened intervals are listed in Table 2.1. Notice that wells 59-1C and GW-769 are much deeper than the other wells, piezometers, or sumps. Hydraulic heads and groundwater flow directions may vary 
ORNL-DWG 96M-1075

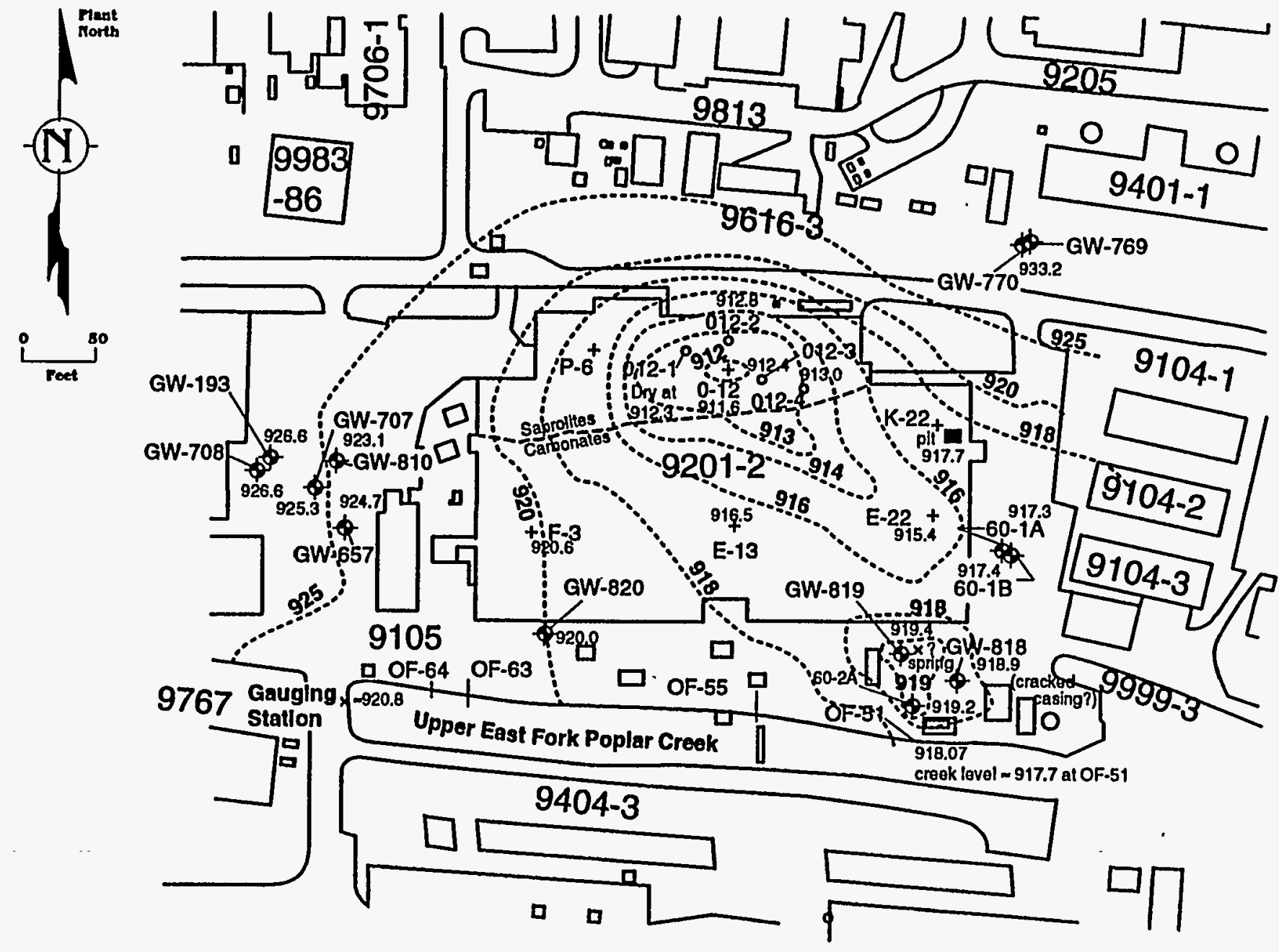

Fig. 1.2. Contours of the elevations of the water table in and around the basement of Bldg. $9201-2$ at 9:00 a.m. to 12 p.m. on July 29, 1994, or shortly before the beginning of the water level recovery test while the sump pumps were still on. The carbonates in the southern portion of the basement are part of the Maynardville Limestone. 


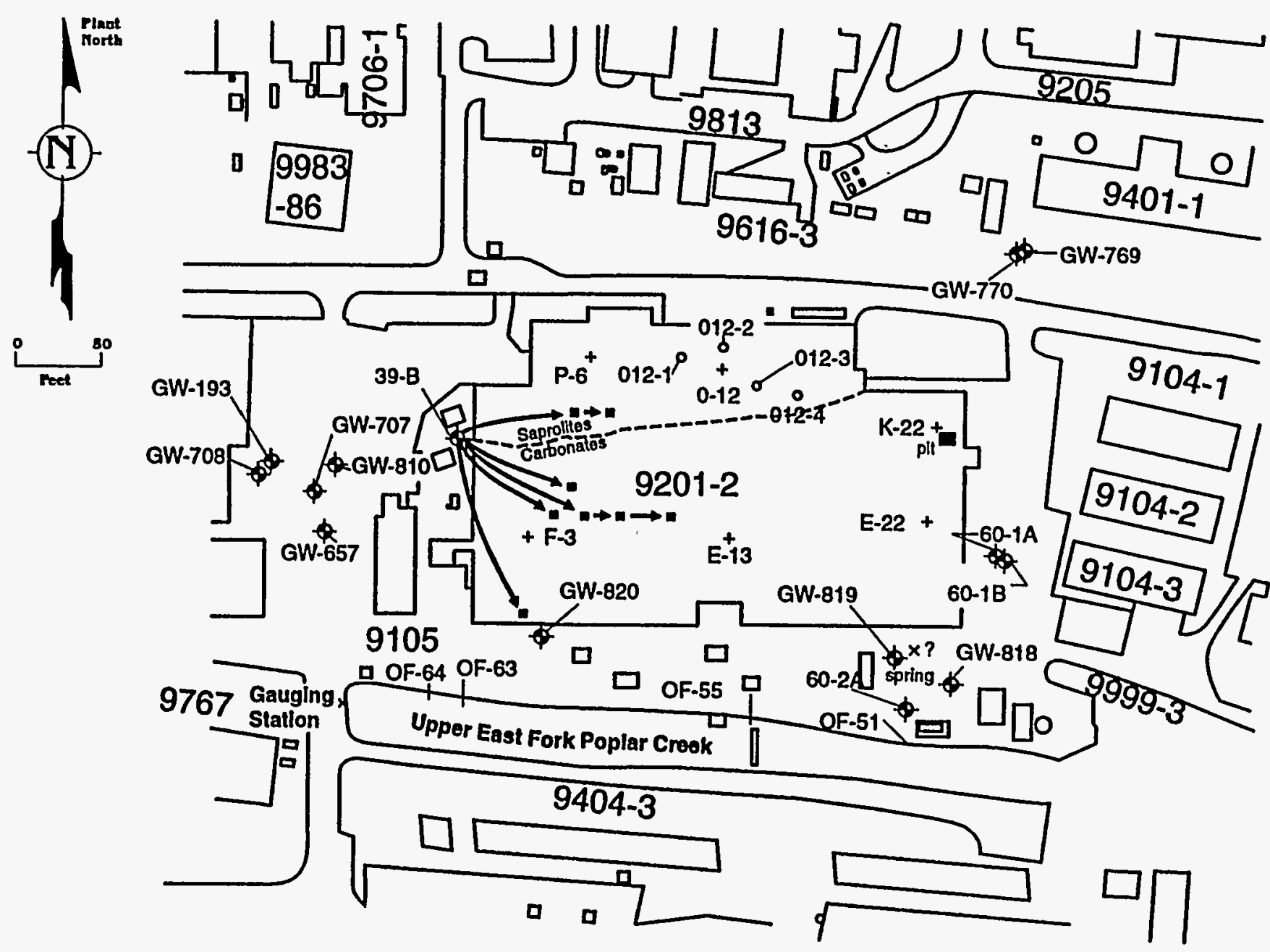

Fig. 1.3. Results of a dye trace test from June 1943, based on approximate locations of drill holes from a construction drawing. The dye was placed in borehole 39-B, which was located to the west of the site of the current building. The dye was located sometime later in eight other boreholes to the northeast, east and south-southeast (based on plant north) of borehole 39-B. 
significantly with depth, and the hydraulic information from the sumps and piezometers inside the basement should be carefully compared with the wells outside of the building, especially the deep wells.

Table 2.1. Sump and top of well/piezometer casing elevations and known screened intervals for the 16 wells closest to Bldg. 9201-2 and the four piezometers near sump 0-12 Jones et al. 1992; HSW Environmental Consultants, Inc. 1994

\begin{tabular}{|c|c|c|c|}
\hline $\begin{array}{c}\begin{array}{c}\text { Identification } \\
\text { number }\end{array} \\
\end{array}$ & Type & $\begin{array}{c}\text { Top of casing or top of sump } \\
\text { elevation } \\
\text { (feet above msl) }\end{array}$ & $\begin{array}{c}\text { Screened interval of } \\
\text { wells/piezometers } \\
\text { (feet above msI) }\end{array}$ \\
\hline $59-1 \mathrm{~A}$ & Well & 945.75 & $932.1-937.1$ \\
\hline $59-1 B$ & Well & 945.69 & $908.2-913.2$ \\
\hline $59-1 \mathrm{C}$ & Well & 945.87 & $871.2-876.2$ (deep) \\
\hline GW-769 & Well & 944.26 & $881.23-893.33($ deep $)$ \\
\hline GW-770 & Well & 944.55 & $922.67-934.17$ \\
\hline E-13 & Sump & 917.87 & - \\
\hline E-22 & Sump & $\begin{array}{c}918.213 \text { (reference point of } 918.57 \\
\text { used during test) }\end{array}$ & - \\
\hline F-3 & Sump & 921.44 & - \\
\hline $\mathrm{K}-22$ & Sump & 921.48 & - \\
\hline $\mathrm{K}-22$ pit & Open pit & 923.50 & - \\
\hline $0-12$ & Sump & 915.075 & - \\
\hline O12-1 & Piezometer & 918.11 & $912.27-913.99$ \\
\hline $012-2$ & Piezometer & 917.31 & $911.58-913.30$ \\
\hline $012-3$ & Piezometer & 916.85 & $911.04-912.76$ \\
\hline $012-4$ & Piezometer & 914.54 & $910.64-912.36$ \\
\hline P-6 & Sump & 913.27 & - \\
\hline $60-1 A$ & Well & 929.69 & $906.1-911.1$ \\
\hline $60-1 B$ & Well & 929.80 & $900.0-905.0$ \\
\hline $60-2 A$ & Well & 929.70 & $914.3-919.3$ \\
\hline GW-818 & Well & 927.925 & 907.67-? (cracked casing?) \\
\hline GW-819 & Well & 928.753 & $913.4 ?-?$ \\
\hline GW-820 & Well & 929.565 & $912.4 ?-?$ \\
\hline GW-810 & Well & 931.44 & $905.9-915.9$ \\
\hline GW-657 & Well & 930.53 & $913.7-926.8$ \\
\hline GW-707 & Well & 930.91 & $905.16-925.66$ \\
\hline GW-708 & Well & 930.87 & $917.33-928.33$ \\
\hline GW-193 & Well & 934.00 & $912.71-925.61$ \\
\hline
\end{tabular}

The water levels in all 16 of the wells were measured weekly from June 28 to August 2, 1994. Water levels in wells 60-1A, 60-1B, 60-2A, GW-818, GW-819, and GW-820, which are closest to the 
building, were first monitored on June 23 and were periodically checked after significant rainfall events. All water level data are listed in the appendix.

Redevelopment of the six wells closest to the building on July 12, 1994, indicated that well GW818 probably has a cracked casing. If so, the results from this well are questionable, although the results are not inconsistent with water levels in nearby wells GW-819 and 60-2A. For example, Fig. 1.2 shows the water level elevations of wells GW-818, GW-819, and 60-2A just before the beginning of the water level recovery test.

The monitoring results from the wells surrounding Bldg. 9201-2 were used to correlate changes in the water table during storms and dry periods and to derive general groundwater flow patterns before the test began. Fig. 2.1, for example, shows the water levels in feet above mean sea level (msl) from June 23 to August 2, 1994 for wells 60-1A, 60-2A, GW-819, and GW-820, which are close to Bldg. 9201-2 (Fig. 1.1). The water levels of the four wells in Fig. 2.1 were significantly affected by precipitation events, especially the 3.01-in. rainfall that occurred on June 26 (all precipitation amounts listed in this report are from records collected at a weather station at the National Oceanic and Atmospheric Administration office in Oak Ridge, Tennessee, which is within 1.5 miles of Bldg. 9201-2).

Historical data from Rothschild et al. (1984) and the Y-12 Plant Groundwater Protection Program were also available for wells 60-1A, 60-1B, and 60-2A on certain dates from December 1983 to February 1986. The historical and current data were useful in showing that the water levels in wells 60 $1 \mathrm{~A}$ and $60-1 \mathrm{~B}$ rarely exced $919 \mathrm{ft}$ above msl and that the water level in $60-2 \mathrm{~A}$ is almost always at least 1 to $2 \mathrm{fthigher}$ than the levels in 60-1A and 60-1B. This information would later prove to be useful in interpreting the subsurface hydrology of the area.

Using pretest data, a large trough was identified in the water table underlying Bldg. 9201-2 (Fig. 1.2). Sumps $0-12, \mathrm{E}-13$, and $\mathrm{E}-22$ are located in the trough. The trough is preferentially elongated in a northwest-southeast direction from plant grid north (plant grid north is approximately $34^{\circ}$ west of true north, unless mentioned otherwise all directions in this report are based on plant grid north). The trough includes an area from the O-12 sump to near the site of an old spring, which is roughly located between wells GW-818 and GW-819 near the southeast corner of the building (Fig. 1.2).

The trough includes a cone of depression in the water table that surrounds the 0-12 sump (Fig. 1.2). The size of the cone is controlled by the pumping rate of the sump. Available data suggest that the cone is partially elliptical with its major axis having an east-west orientation from plant north, which would approximate the strike of the bedrock.

The water level elevation in sump 0-12 is typically 911.5 to $912.0 \mathrm{ft}$ above msl or at least $5 \mathrm{ft}$ below the creek level and the water levels in the six wells closest to the building (i.e., 60-1A, 60-1B, 602A, GW-818, GW-819, and GW-820). The bottom of the Outfall 51 pipe has an elevation of 918.07 $\mathrm{ft}$ above msl, and the base flow level of UEFPC near the outfall is typically $917.7 \mathrm{ft}$ above msl. A gauging station (Station 8) is located on the creek to the southwest of Bldg. 9201-2 (Fig. 1.2). Review of recent records from the gauging station indicate that the creek level at the station is typically around $920.8 \mathrm{ft}$ above msl. The water levels in the six wells closest to the building ranged from 917.3 to 920.0 $\mathrm{ft}$ above msl at 9:30 a.m. July 29, about $3 \mathrm{~h}$ before the water level recovery test began (Fig. 1.2).

On July 8, 1994, four very shallow monitoring wells or piezometers (i.e., 012-1, 012-2, 012-3, and 012-4) were installed in saprolites near sump O-12 and were used to map the cone of depression around the sump (Fig. 1.2). The piezometers are located from the northwest to the east of the sump. Hard carbonate outcrops (i.e., limestones and dolostones of the Maynardville Limestone), pipes and equipment 


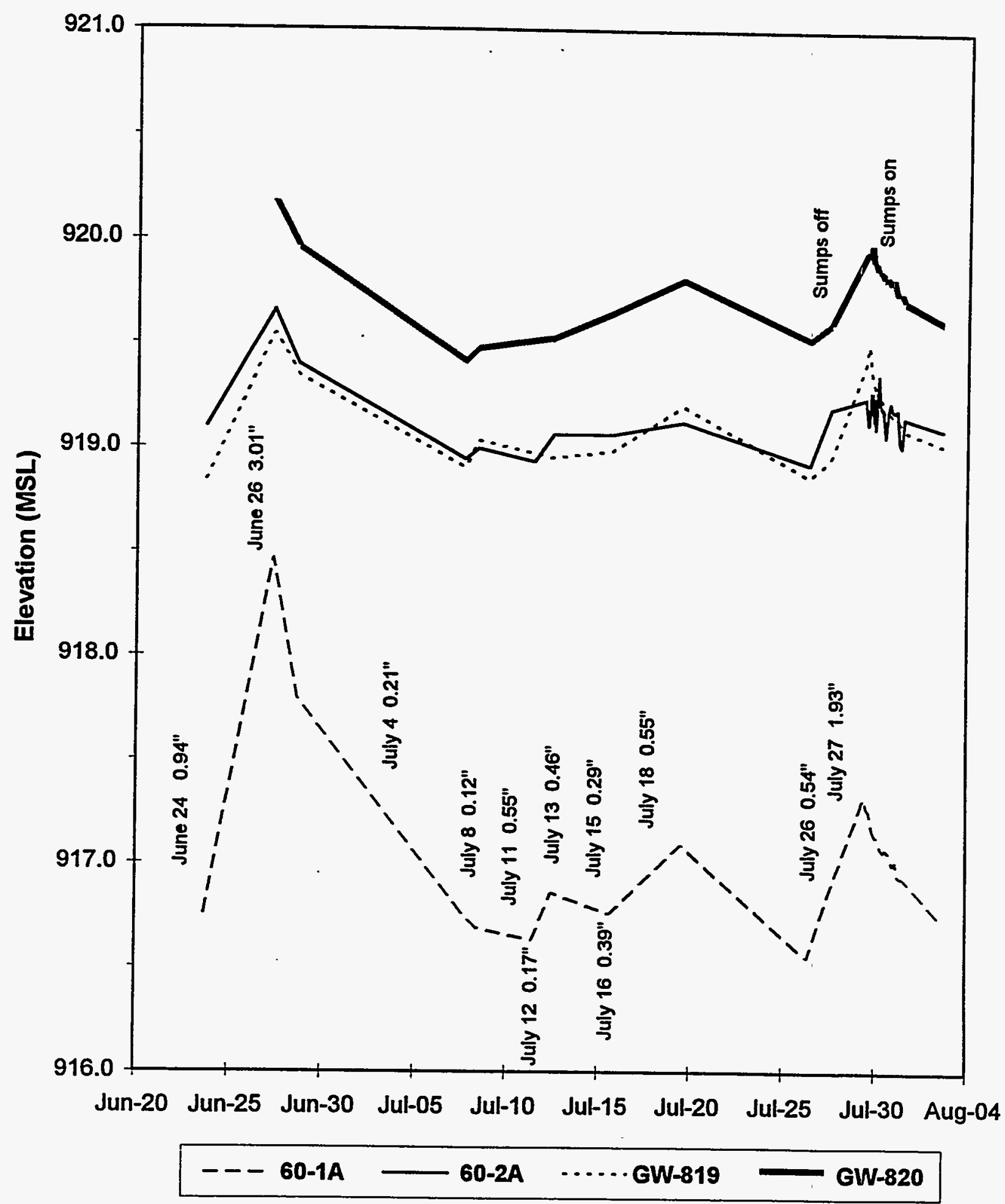

Fig. 21. Changes in the water levels of monitoring wells 60-1A, 60-2A, GW-819, and GW-820 from June 23 to August 2, 1994. The four wells are located near Bldg. 9201-2 (Fig. 1.1). The water levels were significantly affected by precipitation events. The dates of precipitation events exceeding $0.10 \mathrm{in}$. in $24 \mathrm{hr}$ and the amount of precipitation during the $24 \mathrm{hr}$ period are also shown. The precipitation data were collected at a weather station at the National Oceanic and Atmospheric Administration office in Oak Ridge, Tennessee, which is within 1.5 miles of Bldg. 9201-2. 
prevented the hand installation of piezometers to the south of the sump or around the other sumps. The distances and directions between the piezometers and the 0-12 sump are shown in Table 2.2. Since the distances were measured with a tape on an unlevel line, the distances are only listed to the nearest foot.

A Brunton compass was used to determine the directions of the piezometers from the sump. The directions in Table 2.2 are based on true north rather than plant north.

Table 2.2 Distances between the $0-12$ sump and the four $0-12$ piezometers

Sump/piezometer (measurements

from center of casing or sump)
Distance (in feet)
Direction (in degrees from true north from the sump)

$\begin{array}{lll}0-12 \text { to } 012-1 & 29 & 271 \\ 0-12 \text { to } 012-2 & 15 & 328 \\ 012-1 \text { to } 012-2 & 29 & 69 \\ 0-12 \text { to } 012-3 & 32 & 63 \\ 0-12 \text { to } 012-4 & 65 & - \\ 012-3 \text { to } 012-4 & 33 & \end{array}$

Water levels in three of the 0-12 piezometers were first recorded on July 11 (appendix, Water Level Data for Building 9201-2 Sumps, Piezometers, and Wells [June 23 - August 2, 1994]). Piezometer 012-1 remained dry except when the water levels substantially rose during part of the water level recovery test.

The water levels in GW-769, GW-770, and the six wells closest to Bldg. 9201-2 were measured on July 26 (just before a 0.54 -in. rain storm on that day). An additional 1.93 in. of rain fell early on July 27. The water levels in all 16 wells were checked on July 27 after the precipitation had ended. A small amount of precipitation (i.e., 0.03 in.) occurred on July 28; however, this negligible amount of rain is not believed to have significantly affected the water levels of the 16 wells.

\subsection{ACTIVITIES DURING THE WATER LEVEL RECOVERY TEST}

The work plan for the water level recovery test is presented in King (1994). The plan consisted of shutting off the three main sump pumps in the basement of Bldg. $9201-2$ (i.e., O-12, E-13, and E-22, as shown in Fig. 1.2) and monitoring the water level rise in the basement for the next two days. Markings were placed near the 0-12 and E-22 sumps that defined the maximum water level heights that were safe for water-sensitive equipment in the basement. Part of the purpose of the test was to determine whether the water levels would approach the critical markings under dry weather conditions and, if so, how quickly. The performance of the test during dry weather conditions also allowed for a better understanding of the potential hydrologic interactions between UEFPC, the groundwater surrounding the building, and the water in the basement without the complications associated with precipitation. 
On July 29, the day of the initiation of the water level recovery test, all of the outside wells were monitored at 9:30 a.m. and wells 60-1A, 60-1B, 60-2A, GW-818, GW-819, and GW-820 were checked once more at 12:30 p.m. shortly before the sumps were shut off. The pretest water levels in the sumps and piezometers around 0-12 were determined at 11:00 a.m. The 9:30 a.m. and 11:00 a.m. July 29 pretest results are shown in Fig. 1.2.

The measured reference elevation on the top of sump E-22 is $918.213 \mathrm{ft}$ above msl. Although this reference point was used in the pretest measurements, it was not suitably located for quick and easy measurements during the test. A second elevation point on top of the sump was derived and used during the test, which had an elevation of $918.57 \mathrm{ft}$ above msl. Both of these elevation points are shown in the appendix with the appropriate sump E-22 measurements.

The test was initiated by shutting off the pumps in sumps O-12, E-13, and E-22 at approximately 12:45 p.m on July 29, 1994. Sump P-6 was not observed to be operating during the test. The water in sump P-6 is condensate and is located in an entirely concrete-lined pit that is probably effectively isolated from any groundwater. Sump K-22 was dry and inactive during the entire test. The pump in sump F-3 also did not operate during the test, although stagnant water was present. It is not known if the water in sump F-3 is influenced by groundwater or if it is isolated like P-6. As shown in Fig. 1.2, the water level in sump F-3 is consistent with nearby groundwater levels in sump E-13, well GW-820, and the wells to the west side of Bldg. 9201-2.

During the test, all of the basement piezometers and sumps were checked every hour beginning at $45 \mathrm{~min}$ after the sumps were shut off (i.e., 1:30 p.m. July 29). The monitoring of the outside wells began at $1.5 \mathrm{hr}$ into the test (2:15 p.m. July 29). Wells 60-1A, 60-1B, 60-2A, GW-818, GW-819, and GW-820 were monitored once every $2 \mathrm{hr}$, while the other 10 , more distant, outside wells were checked every $4 \mathrm{hr}$. There were some problems with one of the water level meters, which caused two of the early measurements on well GW-819 (i.e., at 2:19 p.m. and 4:12 p.m. on July 29) to be suspect. Evaluation of all of the data at the end of the test resulted in the exclusion of these two measurements from this report.

By $9 \mathrm{hr}$ after the initiation of the test, it was apparent that water levels in some of the sumps were not changing. Beginning at the ninth hour of the test, sumps F-3, P-6, K-22, and the pit near $\mathrm{K}-22$ were only monitored every $2 \mathrm{hr}$. At $14 \mathrm{hr}$ into the test, the water levels in F-3, P-6, and the pit near K-22 still had not significantly changed and K-22 was still dry. Therefore, the frequency of the water level monitoring of these three sumps and the K-22 pit was reduced to every $3 \mathrm{hr}$.

The rise of the water levels in sumps E-13, E-22, 0-12 and the four 0-12 piezometers slowed significantly by the 26th hour into the test, so they were only monitored every $2 \mathrm{hr}$. By the 30 th hour of the test, the rising water levels at sump 0-12 and piezometer 012-4 made it more difficult to obtain reliable measurements with the bulky water level meters and their tape measures. Measurements with the water level meters continued, but staff gauges, which had been installed near sump 0-12 and piezometer 012-4 and which were now partially covered with water, provided valuable duplicate measurements of the water levels. Two staff gauges were also installed near sump E-13, although the water never rose significantly around them.

Because of darkness, monitoring personnel were unable to locate well GW-810 at 35, 38, and 41 hr into the test (midnight, 2:56 a.m., and 6:23 a.m. on July 31). However, the missing data were not critical to the interpretations of the test. The measured water levels in GW-810 on July 30 and August 2 are not significantly different and more complete data are available from nearby wells GW-707 and GW-657 (appendix, Fig. 1.2). 
By the morning of July 31 , the rise in the water levels in all of the piezometers and sumps had significantly slowed. None of the inside water levels were rising by more than about $0.02 \mathrm{fthr}$. The elevation of the water level in the 0-12 sump was still at least $1 \mathrm{ft}$ below the cut-off level for equipment protection. Furthermore, the basement near sump E-22, in which water-sensitive equipment was located, was completely dry. The end of the test was planned for noon on July 31,1994 , but the water levels were so stationary that the test was ended early. Sump pumps 0-12, E-13, and E-22 were reactivated at 8:22 a.m. July 31 . No rain had occurred during the $43.5-\mathrm{hr}$ test. Additional water level measurements on sump 0-12 and the four nearby piezometers were made from 8:22 a.m. to 5:55 p.m. on July 31 to monitor the drawdown. The post-test drawdown results are discussed below.

\subsection{REVIEW OF DATA QUALITY}

The water level data were entered into a Microsoft Excel@ spreadsheet and evaluated. These data are listed in the appendix. Four data points from the test were considered suspect. These anomalous points were either not entered into the spreadsheet or were corrected on the basis of duplicate staff gauge measurements or from the results of earlier and later measurements. For example, the 14th hour (2:39 a.m., July 30) measurement on sump 0-12 was not consistent with the duplicate sump 0-12 staff gauge measurement and earlier and later data from the sump. The staff gauge measurement represented the most likely water level value for that time and was entered into the spreadsheet. The anomalous measurement was about $0.07 \mathrm{ft}$ higher than the more realistic staff gauge measurement.

Data comparisons with earlier and later measurements also revealed that a measurement at piezometer 012-2 at $11 \mathrm{hr}$ into the test (11:36 p.m., July 29) was probably $3.93 \mathrm{ft}$ rather than $3.63 \mathrm{ft}$. As mentioned earlier, a couple of data points from well GW-819 were considered unreliable because of an equipment malfunction and were not entered into the spreadsheet.

\section{RESULTS AND CONCLUSIONS}

The results from the test and the conclusions on the hydrology of the area are presented for each of the sumps, the outside wells as a group, and then summarized for the entire area around the building.

\subsection{SUMP 0-12 AND PIEZOMETERS}

The pretest data show that a cone of depression in the water table normally exists around the 0-12 sump, resulting from large amounts of water that are typically pumped from the sump (Fig. 1.2). The average pumping rate of the $0-12$ sump is usually between 5 and $10 \mathrm{gal} / \mathrm{min}(\mathrm{gpm})$, which is based on periodic readings of the sump meter divided by the entire time period between consecutive meter readings. Although the water level in the $0-12$ sump is usually between 911.5 and $912.0 \mathrm{ft}$ above msl, water stains on building columns indicate that during heavy rainfall events (such as the 4.89 -in. storm that occurred on December 4, 1993) the water level in the sump may rise to slightly above $915 \mathrm{ft}$ above msl.

As seen in Fig. 1.2, the pretest water level measurements at the 0-12 sump and three of the four piezometers (i.e., O12-1 was dry) suggest that the cone of depression has a partially elliptical shape. The major axis of the ellipse may approximately parallel the typical $\mathrm{N} 55^{\circ} \mathrm{E}$ (from true north) strike of the 
bedding planes of the bedrock or essentially east-west based on plant grid north. As expected, water tends to travel more easily along the bedding planes of bedrock rather than perpendicular to the planes. There may also be unidentified drains in the subsurface affecting the flow of water to the 0-12 sump, as well as to the other sumps.

An easterly flow of the groundwater underneath the west side of Bldg. 9201-2 is suggested by water level data from wells GW-193, GW-708, GW-707, GW-657, GW-810, and GW-820 (Fig. 1.2). The easterly flow is also consistent with the previously discussed 1943 dye test (Fig. 1.3).

During the water level recovery test, the cone of depression associated with sump 0-12 and its piezometers largely disappeared (Fig. 3.1). Water levels in the 0-12 sump and the four associated piezometers rose to 914.0 to $914.1 \mathrm{ft}$ above $\mathrm{msl}$. The water in the $0-12$ sump was rising at the end of the test at about $0.02 \mathrm{ft} / \mathrm{hr}$, compared with about $0.7 \mathrm{ft}$ in the first $45 \mathrm{~min}$ of the test. The water level rise produced a large pond around the 0-12 sump, which became difficult to cross (Fig. 3.1). At the end of the test, the pond was 2 to $3 \mathrm{ft}$ deep and at least $20 \mathrm{ft}$ wide near sump 0-12. The pond extended to the east of sump 0-12 and surrounded piezometer 012-4 (Fig. 3.1).

Most of the trough in the water table, which includes sumps E-22 and E-13, persisted throughout the test (Figs. 1.2 and 3.1). The water level at the 0-12 sump at the end of the test was $914.0 \mathrm{ft}$ above msl, while the water elevations at E-22, E-13, the pit near K-22, and wells 60-1A and 60-1B were at least $1.8 \mathrm{ft}$ higher. Possible causes of the trough are discussed below.

After the pumps in 0-12 and the other sumps were reactivated at 8:22 a.m. on July 31 , the pump in sump 0-12 removed 26,269 gal of water during the next $9.5 \mathrm{hr}$ to lower the water level in the sump from 914.0 to $911.7 \mathrm{ft}$ above msl. In contrast, the pump in sump E-22 only removed 147 gal during the same 9.5-hr period (see Section 3.6). Table 3.1 lists the number of gallons that were pumped and the average pumping rate for sump $0-12$ during the 9.5 -hr period. The pumping rates were derived by subtracting consecutive meter readings and dividing by the total time period between the consecutive readings. While the pump in sump 0-12 normally removes 5 to $10 \mathrm{gpm}, 61$ to $62 \mathrm{gpm}$ were being pumped from at least 8:22 a.m. to 2:10 p.m. on July 31 .

Table 3.1. Gallons of water pumped from $0-12$ sump during the first $9.5 \mathrm{hr}$ after the end of the water level recovery test

\begin{tabular}{cccc}
\hline Time on July 31 & $\begin{array}{c}\text { O-12 meter reading } \\
\text { (gallons) }\end{array}$ & $\begin{array}{c}\text { No. of gallons pumped } \\
\text { from restart of } \\
\text { O-12 sump pump }\end{array}$ & $\begin{array}{c}\text { Avg. gallons/minute } \\
\text { from restart of 0-12 } \\
\text { sump }\end{array}$ \\
\hline 8:22 a.m. & 799531 & 0(sump pump restarted) & - \\
9:46 a.m. & 804720 & 5189 & 62 \\
11:04 a.m. & 809400 & 9869 & 61 \\
12:12 p.m. & 813600 & 14,069 & 62 \\
2:10 p.m. (14:10) & 820670 & 21,139 & 61 \\
5:55 p.m. (17:55) & 825800 & 26,269 & 46 \\
\hline
\end{tabular}




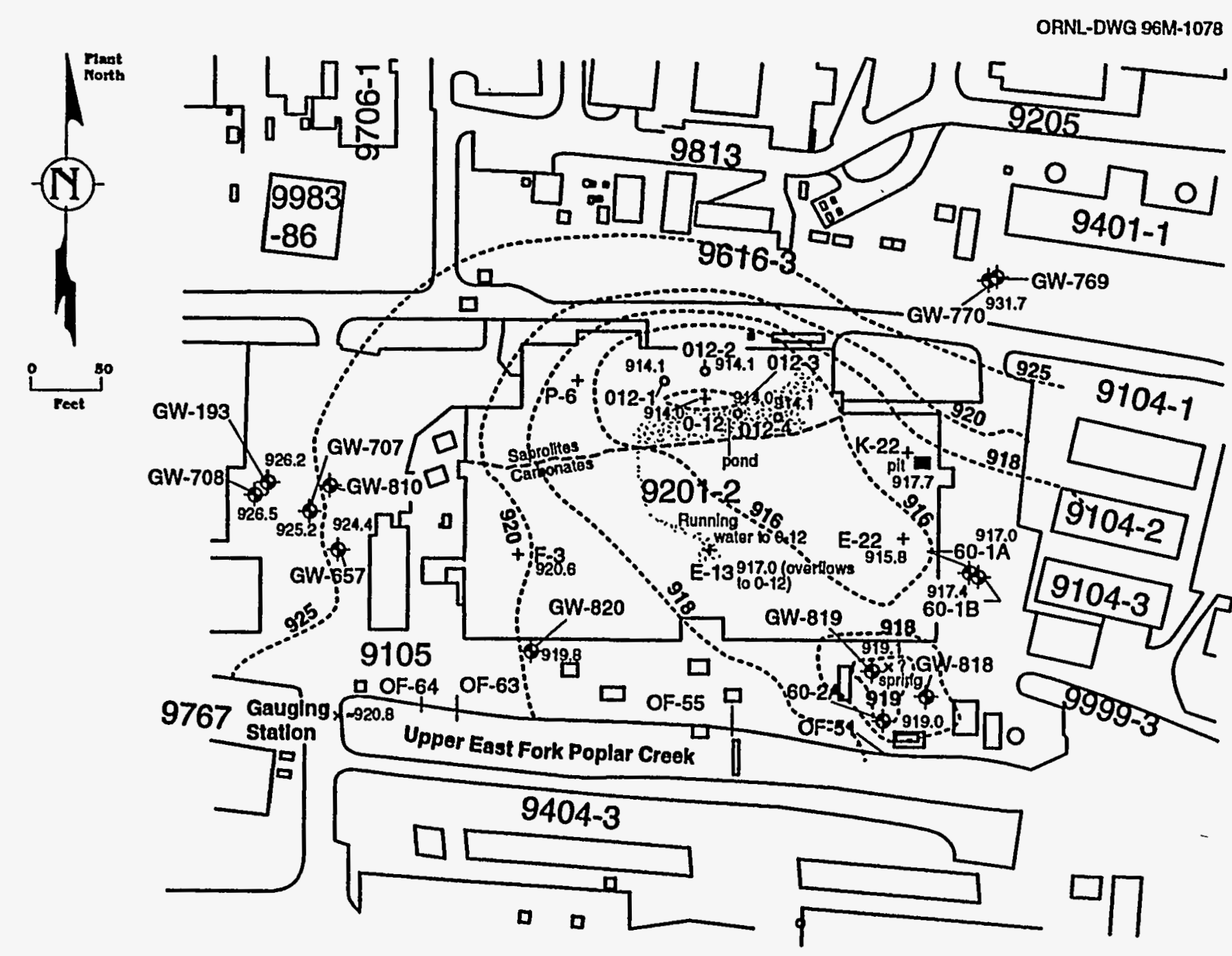

Fig. 3.1. Contours of the elevations of the water table in and around the basement of Bldg. $9201-2$ near the end of the water level recovery test, 6:30 a.m., July 31 , 1994 or approximately $\mathbf{4 2} \mathrm{hr}$ after the test began and the sump pumps had been turned off. The shaded area shows the location of a pond that resulted from the water rise. 


\subsection{SUMP K-22}

The bottom of the $\mathrm{K}-22$ sump was moist before the test. However, at no time during the test did water rise into the sump. The bottom of the sump has an elevation of approximately $920 \mathrm{ft}$ above msl.

Water existed in a pit near sump K-22 before and during the test. The elevation of the top of the standing water was $917.7 \mathrm{ft}$ above msl. The water level did not change during the test. It is not known whether the water in the pit is influenced by groundwater. However, the elevation of the surface of the standing water is close to the expected elevation of the water table based on water levels of around 917 $\mathrm{ft}$ in nearby wells 60-1A and 60-1B.

\subsection{SUMP P-6}

No significant $(t /-0.01 \mathrm{ft})$ changes occurred in the water level of sump P-6 during the test. The water in this sump is condensate and is probably effectively isolated from any groundwater.

\subsection{SUMP F-3}

The water level in sump F-3 did not substantially change during the test. The water level remained at $920.6 \mathrm{ft}$ above msl, which is consistent with the estimated elevation of the water table.

\subsection{SUMP E-13}

The initial water level in sump E-13 was $916.5 \mathrm{ft}$ above msl. After the sump pump was shut off, the water level rose to $917.0 \mathrm{ft}$ above msl within $7.5 \mathrm{hr}$. After $7.5 \mathrm{hr}$, the water apparently began to enter a dug channel in the basement floor and flow to the O-12 sump. As shown in Figs. 3.2 and 3.3 and the appendix, once the water began to drain to sump 0-12, the water level elevation remained essentially constant at $917.0 \mathrm{ft}$ above $\mathrm{msl}$ for the rest of the test.

By $7 \mathrm{hr}$ into the test, the concrete floor surrounding sump E-13 was wet. The water on the floor would eventually rise to approximately $1 \mathrm{in}$. deep before the sump pump was restarted at the end of the test.

\subsection{SUMP E-22}

The water level in sump E-22 rose from 915.4 to $915.8 \mathrm{ft}$ above msl during the test. During the first $11 \mathrm{hr}$ of the test, the water level rise was extremely slow $(0.01 \mathrm{ft} / \mathrm{hr}$ or less). Later, the water level rise increased to slightly more than $0.01 \mathrm{ft} / \mathrm{hr}$. The concrete basement floor near E-22 remained completely dry during the test. Only $147 \mathrm{gal}$ of water were pumped from E-22 during the $9.5-\mathrm{hr}$ period after the end of the test (8:22 a.m. to 5:55 p.m. on July 31).

\subsection{OUTSIDE WELLS}

Besides the monitoring on the outside wells that was done during the test, wells $60-1 \mathrm{~A}, 60-1 \mathrm{~B}, 60$ $2 A, G W-818, G W-819$, and GW-820 were checked at 9:00 a.m. and noon on July 31 shortly after the 


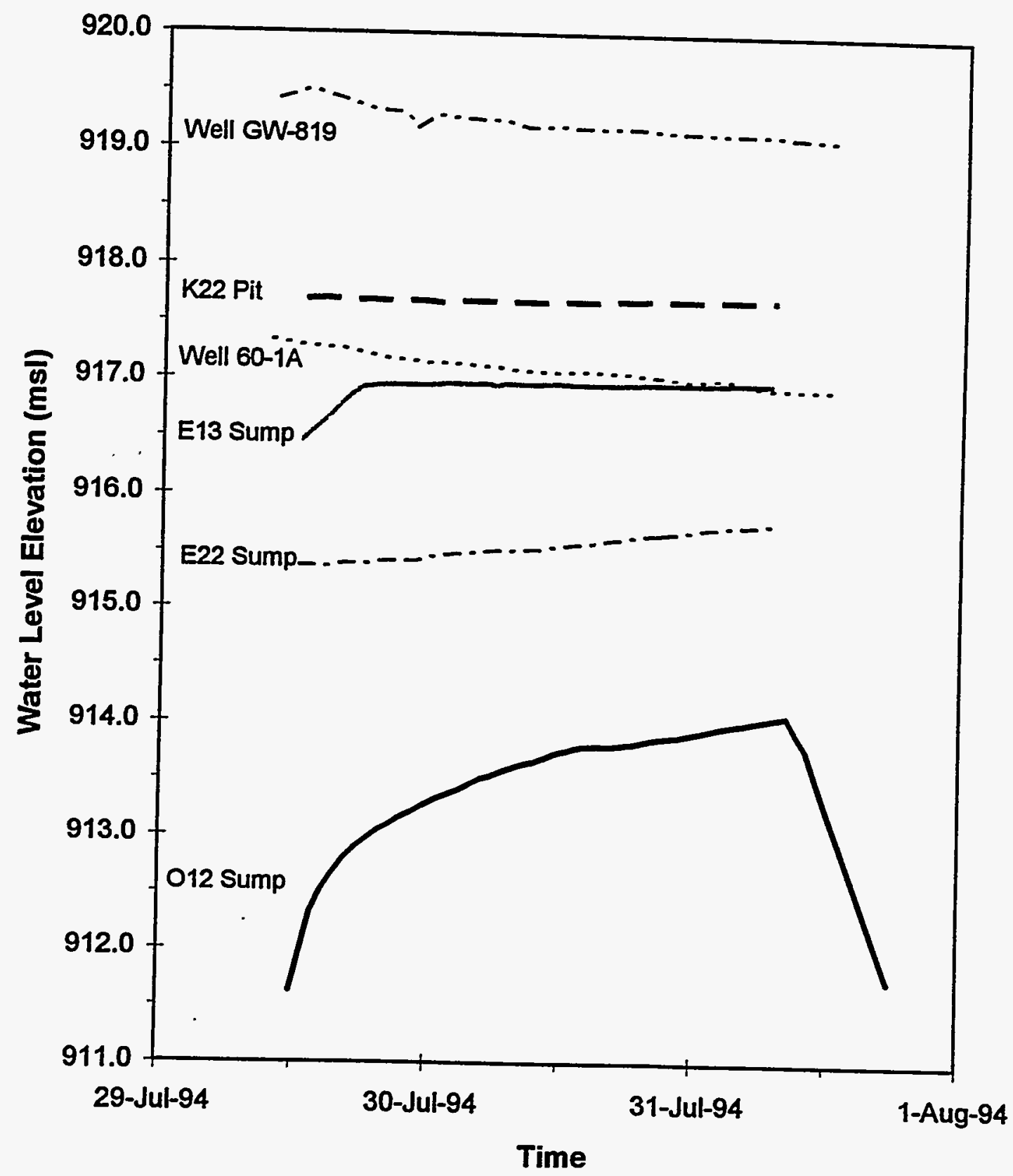

Fig. 3.2. Changes in the elevations of water levels in well GW-819, K-22 pit, well 60-1A, E-13 sump, E-22 sump, and 0-12 sump during the water level recovery test of July 29-31, 1994. 


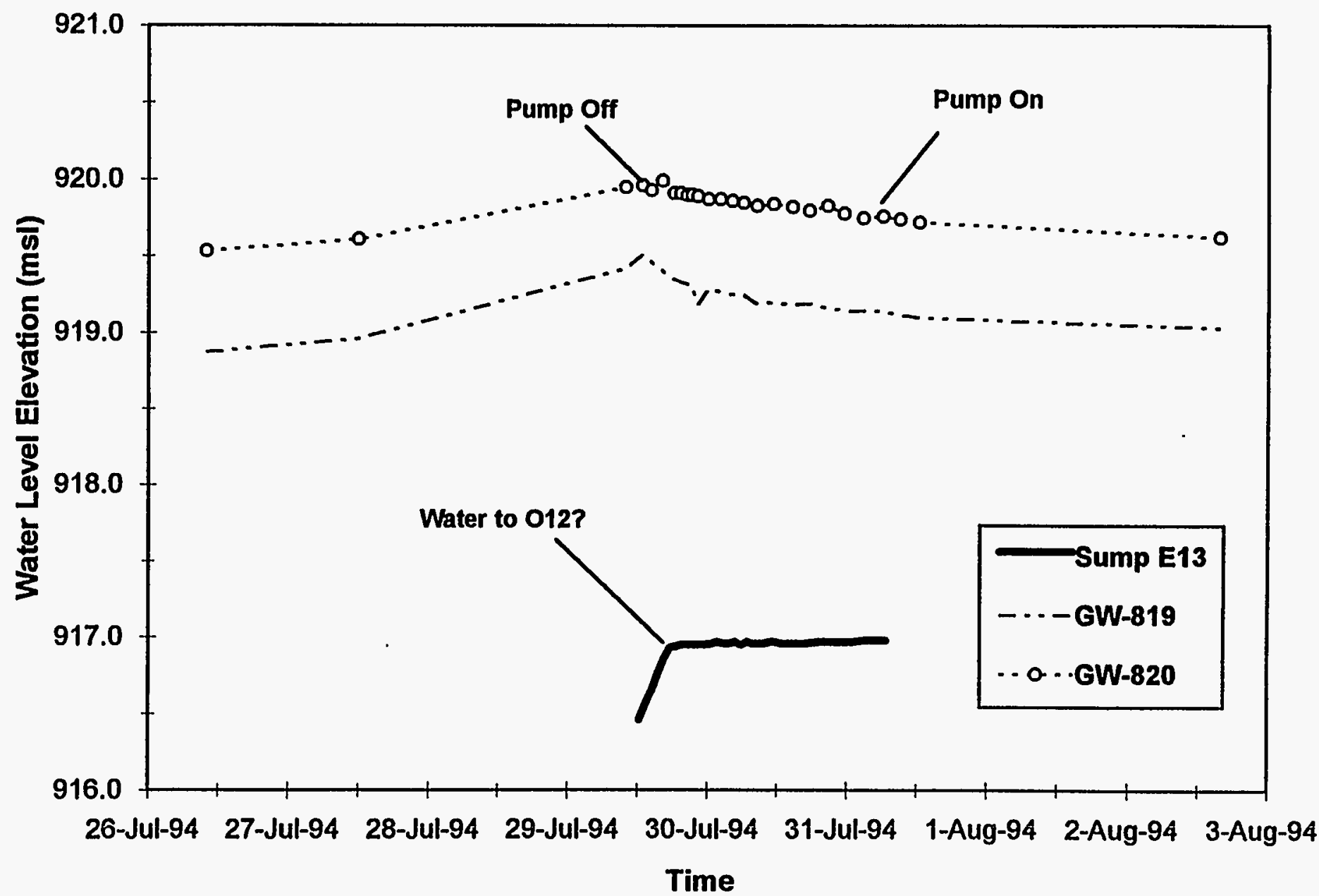

Fig. 3.3. Changes in the elevations of water levels in the E-13 sump during the water level recovery test of July 29-31, 1994 and wells GW-819 and GW-820 from July 26 to August 2, 1994. 
test had ended, and all 16 of the wells were checked again on August 2. There was no rain from July 29 through August 2.

As shown in Fig. 2.1 and more clearly in Figs. 3.2 through 3.4, the water levels in wells 60-1A, GW-819, and GW-820 increased during and shortly after the 2.50 in. of precipitation that fell on July 26-28 (i.e., 0.54 in. on July $26,1.93$ in. on July 27 , and 0.03 in. on July 28) and then declined during the water level recovery test of July 29 through 31 .

The data in the appendix show no conclusive evidence that water levels in any of the outside monitoring wells were affected by the inactivities of the sumps during the test. Specifically, as shown in Figs. 3.2 through 3.4, the water levels in some of the closest wells to Bldg. 9201-2 continued to fall at a fairly steady rate during and after the test, while water levels rose during the test in sumps $0-12, \mathrm{E}$ 22, and E-13. For unknown reasons, the water level in well 60-2A noticeably fluctuated (i.e., 919.0 $919.4 \mathrm{ft}$ above msl) during the water level recovery test (Fig. 2.1; appendix). However, the overall trend in the water level for well $60-2 \mathrm{~A}$ from July 29 to August 2 was downward. This well is more closely located to UEFPC than the other 15 wells (Fig. 1.1).

\subsection{OVERVIEW OF SUBSURFACE HYDROLOGY OF THE AREA}

As noted previously, a trough typically exists in the water table below Bldg. 9201-2. The trough includes the cone of depression around sump 0-12 (Fig. 1.2). The shape and orientation of the trough largely correspond to the topography of the basement and also may be significantly influenced by the presence of permeable fill material in the southeast corner of the building (Fig. 1.1). Other factors that may be affecting the shape and orientation of the trough include possible discharges into the basement from the old spring near the southeast corner of the building, the presence of any permeable gaps in the concrete walls of the building, any old subsurface drains in the basement, a small hill and higher water table to the north of the building, cavities and large fractures in the Maynardville Limestone, and the water level in UEFPC.

Compared to sumps E-13, E-22, and $0-12$, all of the outside wells surrounding the building typically exhibit higher water levels (Fig. 1.2). Wells 59-1A and 59-1B, the shallower of the three wells in the 59-1 cluster, are located on a small hill to the north of Bldg. 9201-2 and are shown in Fig. 1.1. The pretest water level elevations in wells 59-1A and 59-IB at 10 a.m. on July 29 were 941.1 and $943.0 \mathrm{ft}$ above msl, respectively, which are much higher than the levels in the three sumps.

Lines representing the probable groundwater flow directions below and around Bldg. 9201-2 on the moming of July 29 are shown in Fig. 3.5. The flow directions are estimates that were derived from the water level contours in Fig. 1.2, information on the topography of the basement and areas outside of the building, the gradient and location of UEFPC, the orientation of the cone of depression around sump 0-12, the presence of anthropogenic fill material, and the locations of the Maynardville Limestone and Nolichucky Shale and the orientation of their bedding planes.

Available data suggest that the groundwater flow on the western side of the building is dominantly eastward and parallels the bedding planes of the bedrock. However, the water table contours in Figs. 1.2 and 3.1 and the associated flow directions in Fig. 3.5 indicate that the groundwater flow on the eastern side of the building is more complex, especially to the southeast. The large trough in the water table in the basement of the building largely corresponds to the topography of the basement, where the lowest part of the basement and the trough are located near the 0-12 sump (Fig. 1.2). To the south of the 0-12 sump, relatively high outcrops of the Maynardville Limestone occur and the surface elevation of the 


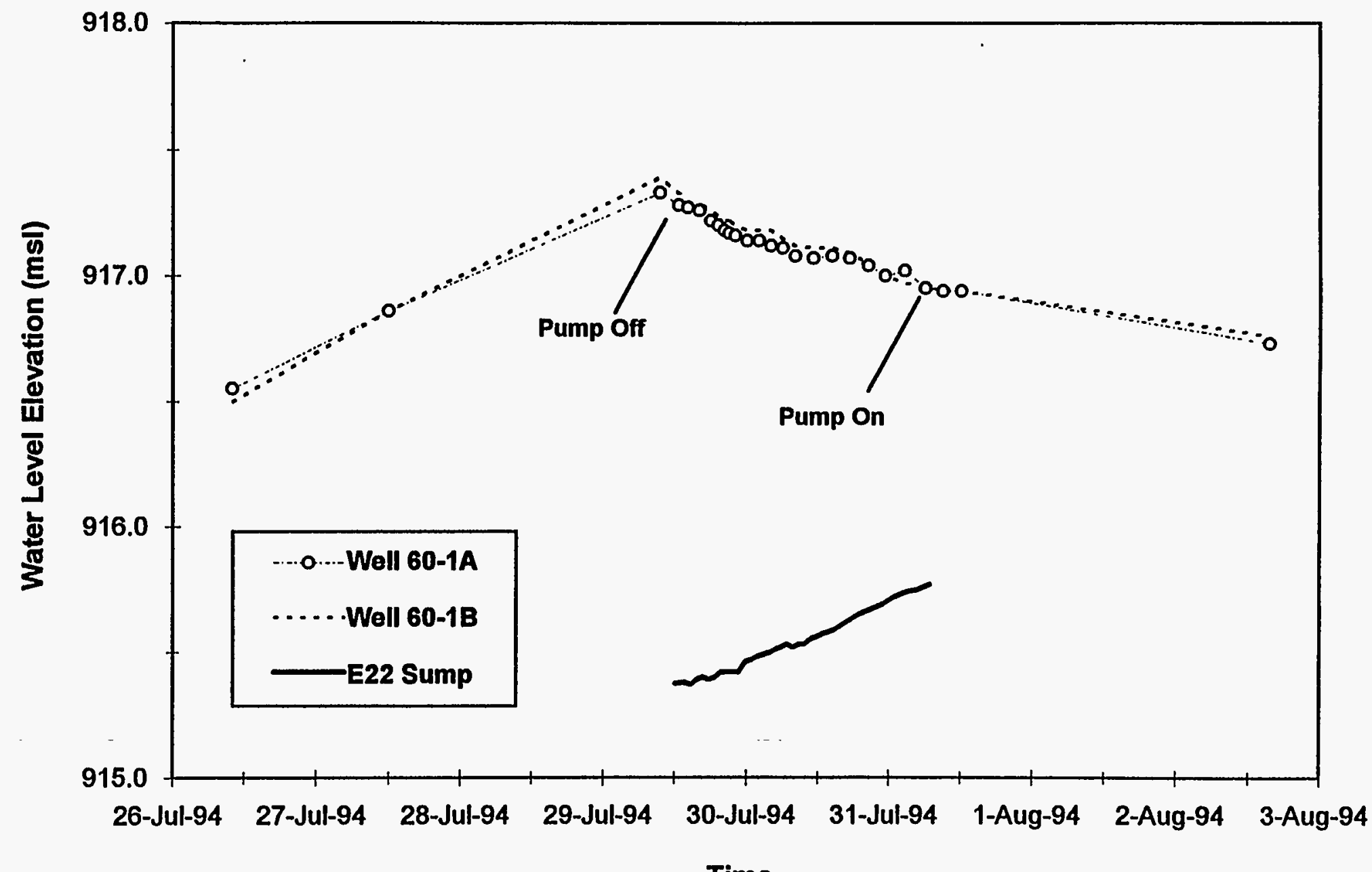

Fig. 3.4. Changes in the elevations of water levels in the E-22 sump during the water level recovery test of July 29-31, 1994 and wells 60-1A and 60-1B from July 26 to August 2, 1994. 


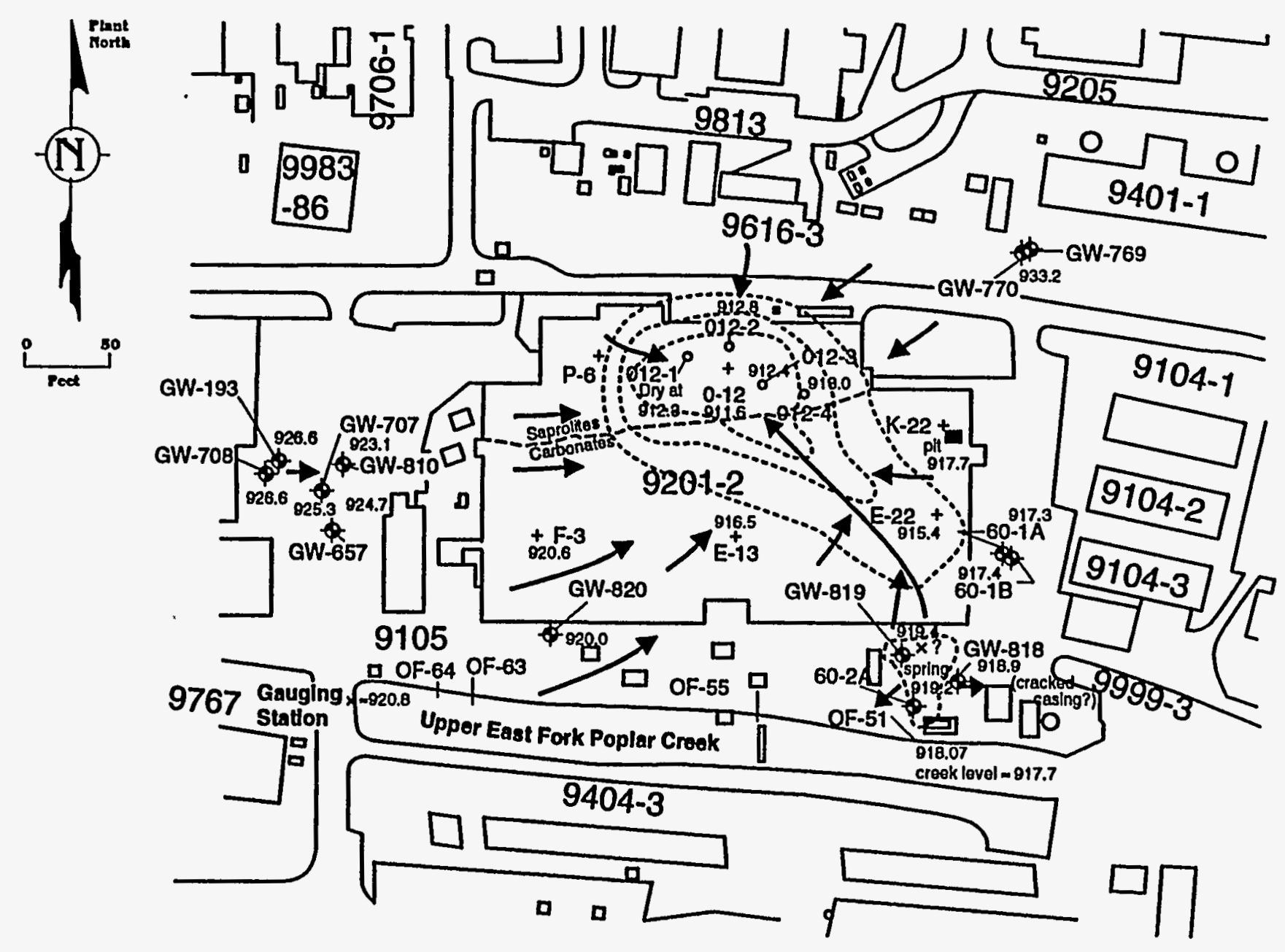

Fig. 3.5. General groundwater flow directions around Bldg. $9201-2$ on the morning of July 29 just before the water level recovery test began. Compare this figure with Fig. 1.2. 
basement increases southward towards the E-13 and E-22 sumps. The elevation of the water table increases with the topography on the south side of the building. Abundant fill material also covers the southeast corner of the building (Sutton and Field, 1995; Fig. 1.1), which could act as a conduit for groundwater from the old spring to the 0-12 sump (Fig. 3.5). Water may also flow into the basement from the hill to the north of the building. When the 0-12 sump was shut off, water levels quickly equilibrated around the 0-12 sump and in the four surrounding piezometers (i.e., filling in the cone of depression). By about $22 \mathrm{hr}$ into the test (10:30 a.m. July 30), the water levels in the 0-12 sump and all four of the 0-12 piezometers equalized at approximately 913.7 feet above msl (Fig. 3.6, appendix).

After the cone of depression was filled at about $22 \mathrm{hr}$ into the test, small volumes of groundwater may have continued to flow from the Maynardville outcrops and other surrounding topographically high areas into the low lying area around the 0-12 sump. Specifically, the water levels in the 0-12 sump and the four surrounding piezometers rose another 0.3 to $0.4 \mathrm{ft}$ after the cone had largely disappeared (i.e., the elevation of the 0-12 sump and the four piezometers rose from about 913.7 to $914.0-914.1 \mathrm{ft}$ above msl during the last $21 \mathrm{hr}$ of the test) as shown in the appendix.

The subsurface hydrology around Bldg. $9201-2$ is also probably significantly affected by any cavities and enlarged fractures in the carbonates associated with the old spring. However, not enough information is currently available to resolve the complex hydrology that would be associated with these karst features. Construction drawings from February 1943 listed the discharge of the old spring at approximately $500 \mathrm{gpm}$ with a water level elevation of $918.4 \mathrm{ft}$ above $\mathrm{msl}$. The throat of the spring had a bottom with an elevation of $896.4 \mathrm{ft}$ above msl. The Maynardville Limestone, in which the spring is located, is known to have long fractures that may be enlarged by dissolution to form extensive underground systems that can transport water over considerable distances to springs (Solomon et al., 1992). In addition, in some areas groundwater from the Nolichucky Shale may flow into the Maynardville Limestone and contribute to the discharge of the spring (Geraghty and Miller, Inc., 1985).

The water discharging out of Outfall 51 probably largely originates from the old spring. A video camera scan of the outfall ended in a constructed chamber with water visibly bubbling into it. The location of the chamber closely corresponds to the location of the former edge of the spring opening and is about $10 \mathrm{ft}$ south of the railroad tracks on the south side of Bldg. 9201-2 or roughly between wells GW-818 and GW-819 (Fig. 1.2). The location and orientation of the outfall suggests that it was probably installed to divert the spring water away from the Bldg. 9201-2 construction site and to UEFPC.

Field observations over the past few years indicate that the discharge from Outfall 51 varies from 80 to $150 \mathrm{gpm}$, far lower than the $500 \mathrm{gpm}$ estimate for the spring in 1943. However, if the water discharging out of Outfall 51 originates from the old spring, 50 years of covering up the recharge zones with buildings and pavement, as well as the possible leakage of some of the spring water into Bldg. 9201-2 may explain the present lower volume of discharge from Outfall 51.

The elevation of the bottom of the Outfall 51 pipe is $918.07 \mathrm{ft}$ above msl and field observations indicate that water is always flowing out of the pipe. If the water originates from the spring, the boil observed in the buried chamber must have an elevation that is higher than the outfall for water to be running out of the pipe, which means that the minimum current elevation for the boil is probably 918.1 $\mathrm{ft}$ above msl.

The creek elevation near Outfall 51 is typically about $917.7 \mathrm{ft}$ above msl or about 1 to $2 \mathrm{ft}$ lower than the water levels in the nearby shallow wells of 60-2A and GW-819 (e.g., Fig. 1.2). In this area, the water table rises from Outfall 51 northward to wells $60-2 A$ and GW-819 (Fig. 3.7). The water levels in 


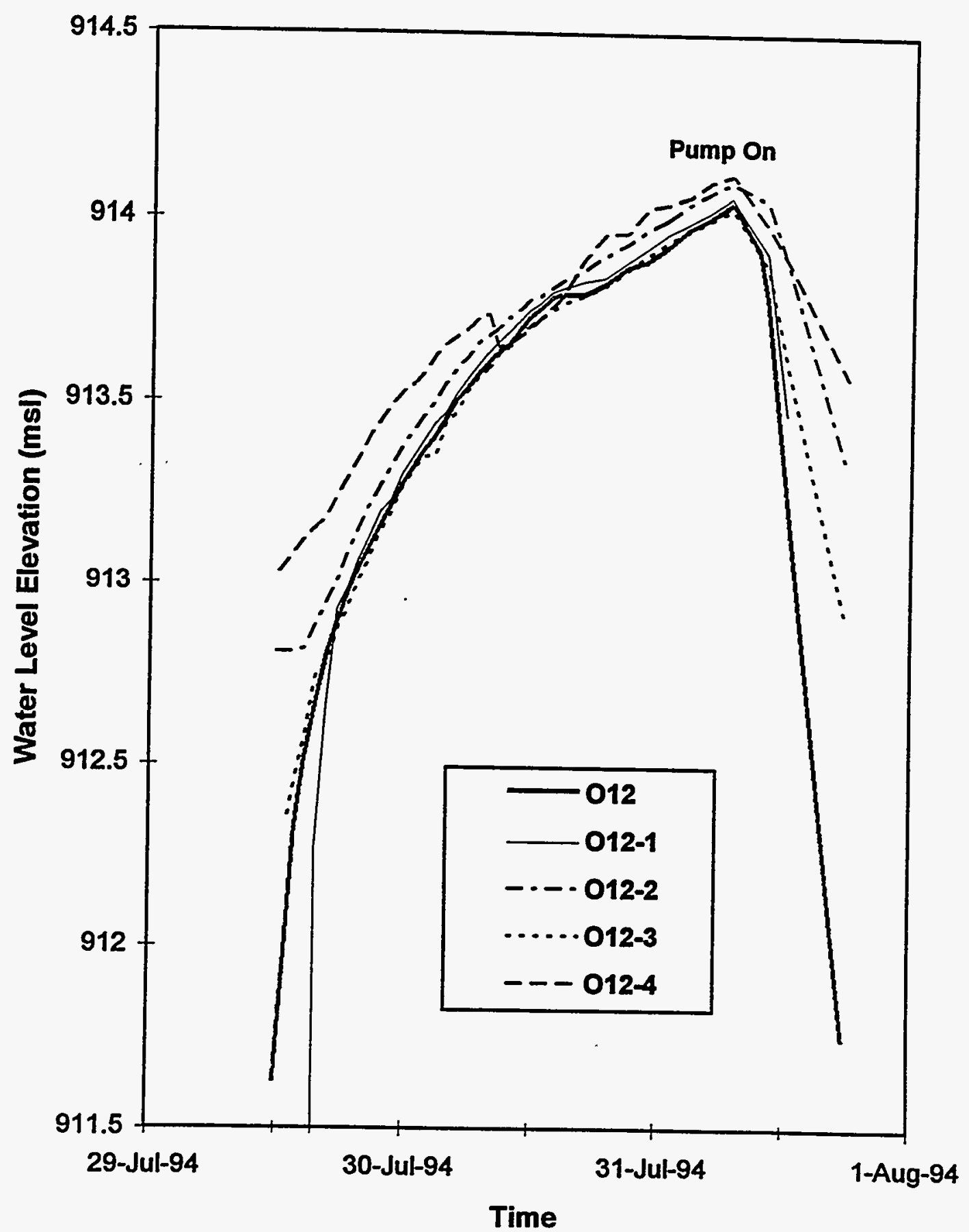

Fig. 3.6. Changes in the water level elevations in sump 0-12 and the four 0-12 piezometers during the water level recovery test of July 29-31, 1994. Because of differences in the elevations of the screening intervals of the four piezometers (see Table 2.1), the water levels began to rise in 012-3 and 012-4 before 012-1 and 012-2. Piezometer 012-1 was initially dry. 
Feet (MSL)

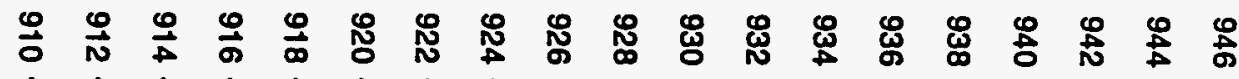

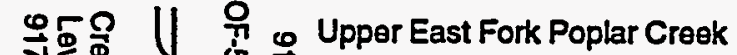

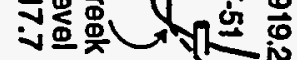
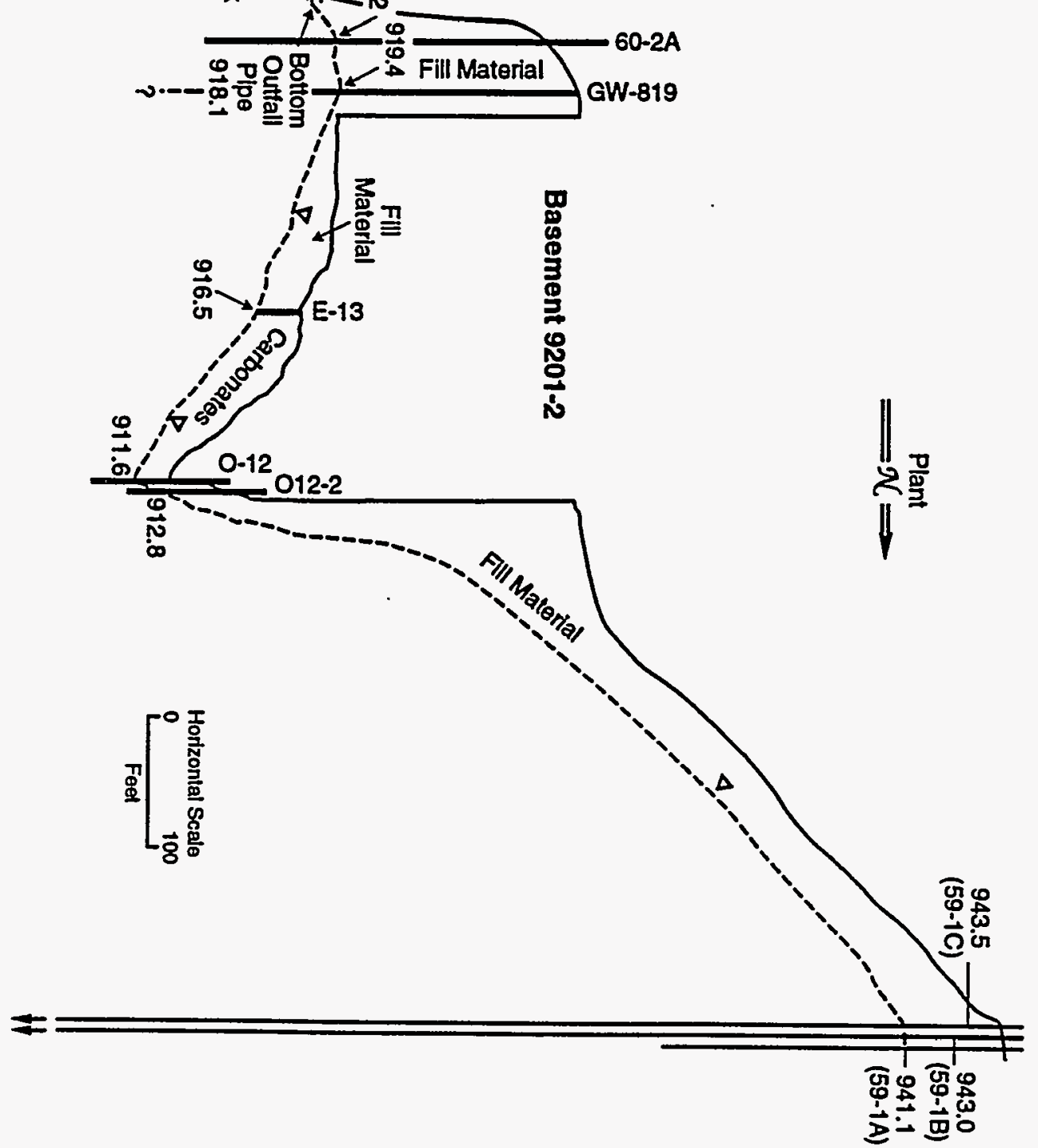
the two wells are also consistently higher (i.e., by about $2 \mathrm{ft}$ ) than the levels in the somewhat deeper wells of 60-1A and 60-1B (Fig. 1.2, appendix, Table 2.1). Discharges associated with the old spring may be elevating the water levels in nearby wells $60-2 \mathrm{~A}$ and $\mathrm{GW}-819$, but not the levels in wells $60-1 \mathrm{~A}$ and 60 1B.

The 1- to 2-ft "mound" of water which exists at wells GW-819 and 60-2A when compared with the typical creek level and the water levels in wells $60-1 \mathrm{~A}$ and $60-1 \mathrm{~B}$ would tend to prevent the movement of creek water near Outfall 51 directly northward into the basement of the building (Fig. 1.2). However, the elevation of the creek at the gauging station (e.g., usually about $920.8 \mathrm{ft}$ above msl), the water table elevations from the wells on the west and southwest sides of the building, and the common occurrence of east-west fractures and cavities in the Maynardville Limestone suggest that it may be possible for some creek water to move into the subsurface and enter the basement on the southwest side of the building (Fig. 3.5).

\section{RECOMMENDATIONS}

On the basis of the results of this study, the following recommendations may be made:

1. Except during months when intense and/or high volume rainfall is likely (winter and early spring) and as long as the mercury concentration of the water does not significantly increase above current levels and remain high, the water level in the 0-12 sump could be allowed to stabilize at $913 \mathrm{ft}$ above msl or about 1 to $1.5 \mathrm{ft}$ above current typical levels.

Maintaining the 0-12 sump level at about $912 \mathrm{ft}$ above msl would provide more surge capacity during heavy rainfall than a higher level, but at the expense of the need to treat more water to maintain this capacity during the entire year. An increase in the water level would largely eliminate the cone of depression around the 0-12 sump and should significantly reduce the large volumes of water that are currently being pumped from this sump and treated for mercury. Typically, the water in the 0-12 sump has an unfiltered mercury concentration of about 4 micrograms per liter $(\mu \mathrm{g} / \mathrm{l})$. However, unfiltered samples of the water in the 0-12 sump at the end of the water level recovery test contained $28 \mu \mathrm{g} / \mathrm{l}$ of mercury. Therefore, the mercury concentration should be monitored if the water level is allowed to stabilize at $913 \mathrm{ft}$ above msl. Furthermore, allowing the water levels to rise in the basement may require the construction of scaffolding to allow personnel to safely and conveniently cross the pool of water which would develop immediately south of sump 0-12 (Fig. 3.1).

Since intense rainfall events, such as the 4.89-in. storm that occurred on December 4, 1993, may raise the water level at the sump to at least $915 \mathrm{ft}$ above $\mathrm{msl}$, a water level of $913 \mathrm{ft}$ above msl would need to be monitored or lowered during seasons with abundant severe storms. A similar water level recovery test during the rainy season may provide additional useful results such as indicating whether or not the 0-12 water level could be allowed to safely stabilize at elevations above $913 \mathrm{ft}$ above msl.

2. The water level in $\mathbf{E}-22$ could be allowed to stabilize at $915.8 \mathrm{ft}$ above $\mathrm{msl}$ or about 5 in. above the current typical water level elevation. As with the 0-12 sump, the higher water level should not threaten any equipment and would allow less water to be pumped. Since the amount of water being pumped by the E-22 sump is insignificant when compared with $\mathrm{O}-12$, the economic advantages of a higher water level at E-22 would not be as great as those associated with 0-12. 
3. Low mercury water from E-13 should not be allowed to flow to sump 0-12 where it becomes contaminated with mercury. Unless other contaminants are present in the water, such as radionuclides or volatile organic compounds, the water in the E-13 sump could continue to be pumped, as necessary, directly through Outfall 55 and to the creek. Previous analyses of unfiltered water in E-13 indicates that it is low in mercury (i.e., typically $1.0 \mu \mathrm{g} / \mathrm{l}$ or less, which is below the 2.0 $\mu \mathrm{g} / \mathrm{l}$ U.S. Environmental Protection Agency Maximum Contaminant Level [MCL] for mercury). This water should not be allowed to mix with high mercury water in the 0-12 sump and contribute to the volume of water that has to be pumped and treated.

4. If more information is desired on the subsurface hydrology of the area around Bldg. 92012 , the installation of additional piezometers is recommended. There are still many uncertainties about the complex hydrology underlying and surrounding Bldg. 9201-2. As examples, there are uncertainties about how groundwater may flow across the contact between the saprolites and the Maynardville Limestone and whether water from the creek is entering the building on the southwest side. It is important to better identify the sources and flow of the groundwater in the basement of Bldg. 9201-2 and especially the groundwater that is becoming contaminated with mercury near the 0-12 sump. In 1995, six additional piezometers were installed to better understand the hydrology around Bldg. 9201-2, especially with regard to the old spring and the extent to which any spring water may be entering the southeast side of the basement (Fig. 4.1).

The installation of seven additional piezometers mostly on the western side of the basement and to the southwest of the building along the creek may provide further useful information. One of the seven proposed piezometers could be placed in sump K-22 to obtain an unambiguous groundwater measurement on the extreme eastern side of the building (Fig. 4.1). In addition, sump F-3 could be investigated more thoroughly to confirm that the sump is connected to groundwater. If the sump only contains condensate, a piezometer should be installed on the southwestern side of the basement, if possible, to better define the hydraulic heads of the groundwater on this side of the basement.

Three more piezometers should be placed along the contact between the carbonates and the saprolites on the western side of the basement to better define the groundwater flow direction along this contact. The locations of the three piezometers are only tentatively shown in Fig. 4.1, since their installations would depend on the absence of pipes, equipment, and other obstacles. Two piezometers could be installed along the creek between the gauging station and well 60-2A to determine if water from the creek is flowing into the basement, particularly during stormflow in UEFPC. Some of these piezometers can be inexpensively installed by hand.

\section{ACKNOWLEDGEMENTS}

The authors thank all of the numerous individuals from the Y-12 Plant Health, Safety, Environment and Accountability (HSE\&A) Division that assisted in the monitoring efforts during the water level recovery test including: J. B. Blanton, V. E. Broadway, S. H. Coffin, M. S. Elliott, A. L. Garland, L. L. Heidel, R. D. Leptrone, E. S. Owens, R. C. Rookard, J. L. Sitzler, and J. T. Williams.

The authors also greatly appreciate the review comments from Helen L. King, W. Kevin Jago, C. Steve Walker, and David B. Watson. The research summarized in this report was sponsored by the Environmental Restoration Division, U.S. Department of Energy, under contract DE-AC05-840R21400 


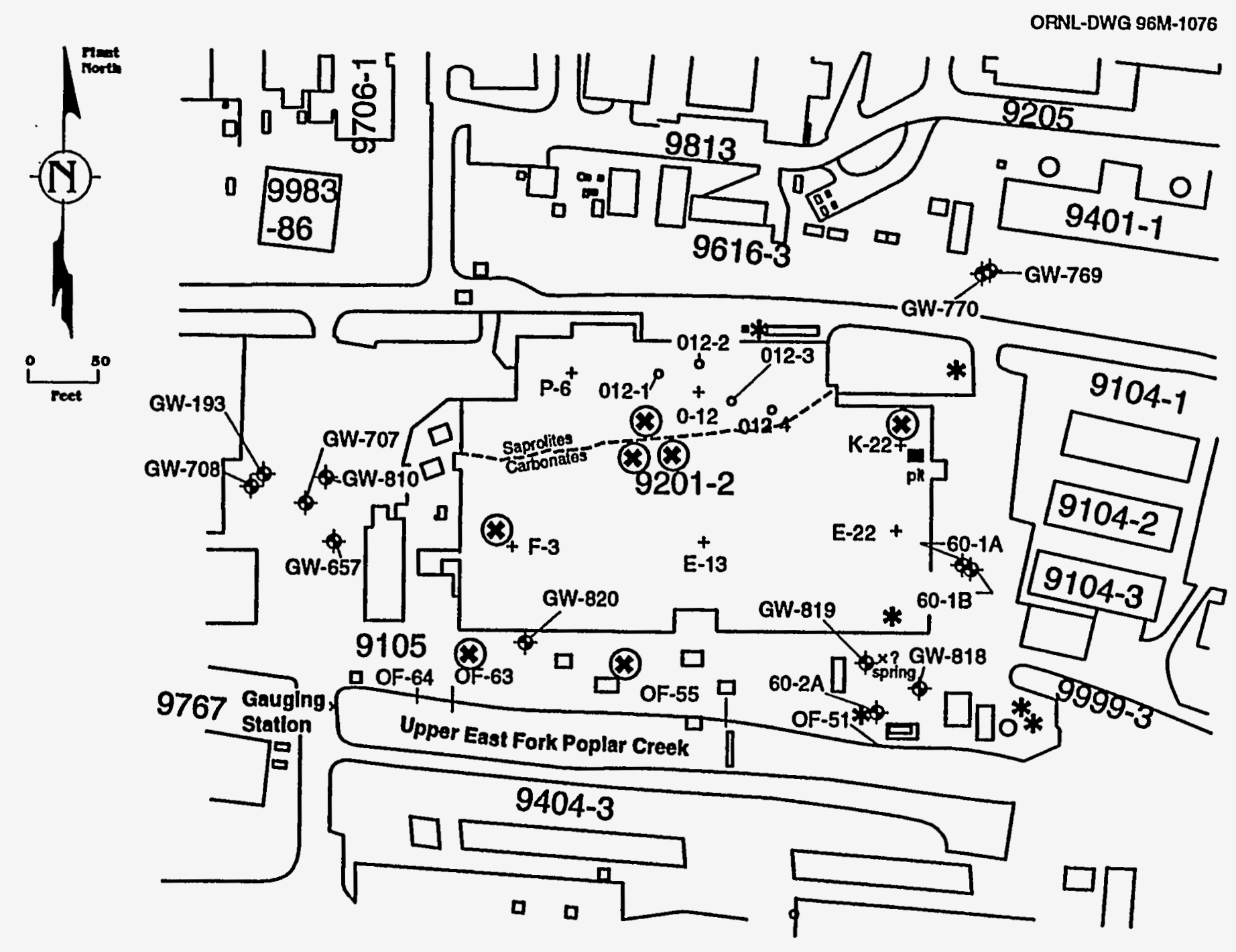

Fig. 4.1. Six piezometers were installed in 1995 in and around the basement of Bldg. 9201-2. Their locations are shown with asterisks in this figure. Another seven piezometers, whose proposed locations are shown with circled $x$ 's on the map, would further improve the understanding of the subsurface hydrology around Bldg. 9201-2. 
with Lockheed Martin Energy Systems, Inc. This research was also supported in part by an appointment of the first author to the Postgraduate Research Program at Oak Ridge National Laboratory administered by the Oak Ridge Institute for Science and Education.

\section{REFERENCES}

Geraghty \& Miller, Inc. 1985. The Relation of Ground Water to Mercury Migration at the Y-12 Plant and the Hydrologic Effects of Proposed Clean-up Measures. Oak Ridge Y-12 Plant. Y/SUB/85$00206 \mathrm{C} / 5$.

HSW Environmental Consultants, Inc. 1994. Calendar Year 1993 Groundwater Quality Report for the UEFPC Hydrogeologic Regime, Y-12 Plant, Oak Ridge, Tennessee: 1993 Groundwater Quality Data and Calculated Rate of Contaminant Migration. Oak Ridge Y-12 Plant. Y/SUB/94EAQ10C/2/P1.

Jones, S.B.; Harrington, B.K.; Field, S.M. 1992. Updated Subsurface Data Base for Bear Creek Valley, Chestnut Ridge, and Parts of Bethel Valley on the U.S. Department of Energy Oak Ridge Reservation, Oak Ridge Y-12 Plant. Y/TS-881.

King, H.L. 1994. Static Water Level Test Plan: Bldg. 9201-2, July, 1994. unpublished. July 26, 1994.

Lanning, J. M. 1993. Aqueous Mercury Treatment Technology Review for NPDES Outfall 49, Y-12 Plant. Y/DZ-1043.

Rothschild, E.R.; Turner, R.R.; Stow, S.H.; Bogle, M.A.; Hyder, L.K.; Sealand, O.M.; and Wyrick, H.J. 1984. Investigation of Subsurface Mercury at Oak Ridge Y-12 Plant, Oak Ridge National Laboratory, Environmental Sciences Division. Pub. No. 2399. ORNL/TM-9092.

Solomon, D.K.; Moore, G.K.; Toran, L.E.; Drier, R.B.; McMaster, W.M. 1992. Status Report: A Hydrologic Framework for the Oak Ridge Reservation, Oak Ridge National Laboratory, Environmental Sciences Division. Pub. No. 3815. ORNL/TM-12026.

Sutton, G.E.; Field, S.M. 1995. Distribution of Anthropogenic Fill Material within the Y-12 Plant Area, Oak Ridge, Tennessee. 


\section{APPENDIX}

WATER LEVEL DATA FOR BLDG. 9201-2 SUMPS, PIEZOMETERS, AND WELLS

(June 23 - August 2, 1994) 


\begin{tabular}{|c|c|c|c|c|}
\hline Date / Time & $\begin{array}{l}\text { Well / Sump } \\
\text { ID }\end{array}$ & $\begin{array}{c}\text { Depth To } \\
\text { Water }\end{array}$ & $\begin{array}{c}\text { Top Of } \\
\text { Casing } \\
\text { Elevation }\end{array}$ & $\begin{array}{l}\text { Water } \\
\text { Elevation }\end{array}$ \\
\hline & & (ft) & (msl) & (msl) \\
\hline $06 / 28 / 9415: 00$ & $59-1 \mathrm{~A}$ & 3.77 & 945.75 & 941.98 \\
\hline $07 / 08 / 9409: 00$ & $59-1 A$ & 4.39 & 945.75 & 941.36 \\
\hline $07 / 12 / 9411: 00$ & $59-1 \mathrm{~A}$ & 4.21 & 945.75 & 941.54 \\
\hline $07 / 19 / 9412: 00$ & $59-1 A$ & 3.81 & 945.75 & 941.94 \\
\hline $07 / 27 / 9412: 00$ & $59-1 A$ & 4.16 & 945.75 & 941.59 \\
\hline $07 / 29 / 9410: 11$ & $59-1 A$ & 4.64 & 945.75 & 941.11 \\
\hline $07 / 29 / 9414: 35$ & $59-1 A$ & 3.68 & 945.75 & 942.07 \\
\hline $07 / 29 / 9418: 37$ & $59-1 A$ & 3.72 & 945.75 & 942.03 \\
\hline $07 / 29 / 9422: 44$ & $59-1 A$ & 3.76 & 945.75 & 941.99 \\
\hline $07 / 30 / 9408: 47$ & $59-1 A$ & 3.80 & 945.75 & 941.95 \\
\hline $07 / 30 / 9414: 50$ & $59-1 \mathrm{~A}$ & 3.82 & 945.75 & 941.93 \\
\hline $07 / 30 / 9417: 41$ & $59-1 A$ & 3.85 & 945.75 & 941.90 \\
\hline $07 / 30 / 9420: 52$ & $59-1 A$ & 3.88 & 945.75 & 941.87 \\
\hline $07 / 31 / 9400: 12$ & $59-1 A$ & 3.88 & 945.75 & 941.87 \\
\hline $07 / 31 / 9402: 52$ & $59-1 A$ & 3.98 & 945.75 & 941.77 \\
\hline $07 / 31 / 9406: 20$ & $59-1 A$ & 3.98 & 945.75 & 941.77 \\
\hline $08 / 02 / 9415: 40$ & $59-1 A$ & 4.14 & 945.75 & 941.55 \\
\hline $06 / 28 / 9415: 00$ & $59-18$ & 2.82 & 945.69 & 942.87 \\
\hline $07 / 08 / 9409: 00$ & $59-1 B$ & 4.01 & 945.69 & 941.68 \\
\hline $07 / 12 / 9411: 00$ & $59-1 B$ & 3.58 & 945.69 & 942.11 \\
\hline $07 / 19 / 9412: 00$ & $59-1 B$ & 2.80 & 945.69 & 942.89 \\
\hline $07 / 27 / 9412: 00$ & $59-1 B$ & 3.30 & 945.69 & 942.39 \\
\hline $07 / 29 / 9410: 13$ & $59-1 B$ & 2.65 & 945.69 & 943.04 \\
\hline $07 / 29 / 9414: 37$ & 59-1B & 2.72 & 945.69 & 942.97 \\
\hline $07 / 29 / 9418: 38$ & $59-1 B$ & 2.77 & 945.69 & 942.92 \\
\hline $07 / 29 / 9422: 46$ & $59-1 B$ & 2.82 & 945.69 & 942.87 \\
\hline $07 / 30 / 9408: 50$ & $59-1 B$ & 2.91 & 945.69 & 942.78 \\
\hline $07 / 30 / 9414: 51$ & $59-1 B$ & 2.98 & 945.69 & 942.71 \\
\hline $07 / 30 / 9417: 42$ & 59-1B & 3.02 & 945.69 & 942.67 \\
\hline $07 / 30 / 9420: 53$ & $59-1 B$ & 3.12 & 945.69 & 942.57 \\
\hline $07 / 31 / 9400: 13$ & $59-1 B$ & 3.14 & 945.69 & 942.55 \\
\hline $07 / 31 / 9402: 53$ & $59-1 B$ & 3.17 & 945.69 & 942.52 \\
\hline $07 / 31 / 9406: 21$ & $59-1 B$ & 3.20 & 945.69 & 942.49 \\
\hline $08 / 02 / 9415: 40$ & 59-1B & 3.53 & 945.69 & 942.16 \\
\hline $06 / 28 / 9415: 00$ & $59-1 C$ & 2.53 & 945.87 & 943.34 \\
\hline $07 / 08 / 9409: 00$ & $59-1 C$ & 3.84 & 945.87 & 942.03 \\
\hline $07 / 12 / 9411: 00$ & $59-1 C$ & 3.32 & 945.87 & 942.55 \\
\hline $07 / 19 / 9412: 00$ & $59-1 C$ & 2.50 & 945.87 & 943.37 \\
\hline $07 / 27 / 9412: 00$ & $59-1 C$ & 2.97 & 945.87 & 942.90 \\
\hline $07 / 29 / 9410: 15$ & $59-1 C$ & 2.34 & 945.87 & 943.53 \\
\hline $07 / 29 / 9414: 39$ & $59-1 C$ & 2.44 & 945.87 & 943.43 \\
\hline $07 / 29 / 9418: 43$ & $59-1 C$ & 2.50 & 945.87 & 943.37 \\
\hline $07 / 29 / 9422: 48$ & $59-1 \mathrm{C}$ & 2.54 & 945.87 & 943.33 \\
\hline $07 / 30 / 9408: 53$ & $59-1 C$ & 2.63 & 945.87 & 943.24 \\
\hline $07 / 30 / 9414: 53$ & $59-1 C$ & 2.73 & 945.87 & 943.14 \\
\hline
\end{tabular}




\begin{tabular}{|c|c|c|c|c|}
\hline Date / Time & $\begin{array}{c}\text { Well / Sump } \\
\text { ID }\end{array}$ & $\begin{array}{l}\text { Depth To } \\
\text { Water . }\end{array}$ & $\begin{array}{c}\text { Top Of } \\
\text { Casing } \\
\text { Elevation }\end{array}$ & $\begin{array}{c}\text { Water } \\
\text { Elevation }\end{array}$ \\
\hline & & $(\mathrm{ft})$ & (msl) & (msl) \\
\hline $07 / 30 / 9417: 43$ & $59-1 C$ & 2.80 & 945.87 & 943.07 \\
\hline $07 / 30 / 9420: 55$ & $59-1 C$ & 2.85 & 945.87 & 943.02 \\
\hline $07 / 31 / 9400: 13$ & $59-1 \mathrm{C}$ & 2.87 & 945.87 & 943.00 \\
\hline $07 / 31 / 9402: 54$ & $59-1 \mathrm{C}$ & 2.90 & 945.87 & 942.97 \\
\hline $07 / 31 / 9406: 22$ & $59-1 C$ & 2.95 & 945.87 & 942.92 \\
\hline $08 / 02 / 9415: 40$ & $59-1 C$ & 3.29 & 945.87 & 942.58 \\
\hline $06 / 23 / 9416: 30$ & $60-1 A$ & 12.94 & 929.69 & 916.75 \\
\hline $06 / 27 / 9408: 00$ & $60-1 A$ & 11.22 & 929.69 & 918.47 \\
\hline $06 / 28 / 9415: 00$ & $60-1 A$ & 11.90 & 929.69 & 917.79 \\
\hline $07 / 07 / 9416: 00$ & $60-1 A$ & 12.94 & 929.69 & 916.75 \\
\hline 07/08/94 09:00 & $60-1 A$ & 13.00 & 929.69 & 916.69 \\
\hline $07 / 11 / 9410: 00$ & $60-1 A$ & 13.06 & 929.69 & 916.63 \\
\hline $07 / 12 / 9411: 00$ & $60-1 A$ & 12.83 & 929.69 & 916.86 \\
\hline $07 / 15 / 9415: 00$ & $60-1 A$ & 12.93 & 929.69 & 916.76 \\
\hline $07 / 19 / 9412: 00$ & $60-1 A$ & 12.59 & 929.69 & 917.10 \\
\hline $07 / 26 / 9409: 00$ & $60-1 A$ & 13.14 & 929.69 & 916.55 \\
\hline $07 / 27 / 9412: 00$ & $60-1 A$ & 12.83 & 929.69 & 916.86 \\
\hline $07 / 29 / 9409: 30$ & $60-1 A$ & 12.36 & 929.69 & 917.33 \\
\hline $07 / 29 / 9412: 38$ & $60-1 A$ & 12.41 & 929.69 & 917.28 \\
\hline $07 / 29 / 9414: 12$ & $60-1 A$ & 12.42 & 929.69 & 917.27 \\
\hline $07 / 29 / 9416: 04$ & $60-1 A$ & 12.43 & 929.69 & 917.26 \\
\hline $07 / 29 / 9418: 00$ & $60-1 \mathrm{~A}$ & 12.47 & 929.69 & 917.22 \\
\hline $07 / 29 / 9419: 10$ & $60-1 A$ & 12.49 & 929.69 & 917.20 \\
\hline $07 / 29 / 9420: 13$ & $60-1 A$ & 12.51 & 929.69 & 917.18 \\
\hline $07 / 29 / 9421: 02$ & $60-1 A$ & 12.52 & 929.69 & 917.17 \\
\hline $07 / 29 / 9422: 05$ & $60-1 A$ & 12.53 & 929.69 & 917.16 \\
\hline 07/30/94 00:00 & $60-1 A$ & 12.55 & 929.69 & 917.14 \\
\hline 07/30/94 02:01 & $60-1 A$ & 12.55 & 929.69 & 917.14 \\
\hline $07 / 30 / 9404: 04$ & $60-1 A$ & 12.57 & 929.69 & 917.12 \\
\hline 07/30/94 06:02 & $60-1 A$ & 12.58 & 929.69 & 917.11 \\
\hline $07 / 30 / 9408: 08$ & $60-1 A$ & 12.61 & 929.69 & 917.08 \\
\hline $07 / 30 / 9411: 08$ & $60-1 A$ & 12.62 & 929.69 & 917.07 \\
\hline $07 / 30 / 9414: 15$ & $60-1 A$ & 12.61 & 929.69 & 917.08 \\
\hline $07 / 30 / 9417: 13$ & $60-1 \mathrm{~A}$ & 12.62 & 929.69 & 917.07 \\
\hline $07 / 30 / 9420: 19$ & $60-1 A$ & 12.65 & 929.69 & 917.04 \\
\hline $07 / 30 / 9423: 11$ & $60-1 A$ & 12.69 & 929.69 & 917.00 \\
\hline $07 / 31 / 9402: 33$ & $60-1 A$ & 12.67 & 929.69 & 917.02 \\
\hline $07 / 31 / 9406: 02$ & $60-1 A$ & 12.74 & 929.69 & 916.95 \\
\hline $07 / 31 / 9409: 00$ & $60-1 A$ & 12.75 & 929.69 & 916.94 \\
\hline $07 / 31 / 9412: 04$ & $60-1 A$ & 12.75 & 929.69 & 916.94 \\
\hline $08 / 02 / 9415: 40$ & $60-1 A$ & 12.96 & 929.69 & 916.73 \\
\hline $06 / 23 / 9416: 30$ & $60-1 B$ & 13.29 & 929.80 & 916.51 \\
\hline $06 / 27 / 9408: 00$ & 60-1B & 11.09 & 929.80 & 918.71 \\
\hline $06 / 28 / 9415: 00$ & 60-1B & 12.00 & 929.80 & 917.80 \\
\hline $07 / 07 / 9416: 00$ & $60-1 \mathrm{~B}$ & 13.19 & 929.80 & 916.61 \\
\hline
\end{tabular}




\begin{tabular}{|c|c|c|c|c|}
\hline Date / Time & $\begin{array}{c}\text { Well / Sump } \\
\text { ID }\end{array}$ & $\begin{array}{c}\text { Depth To } \\
\text { Water }\end{array}$ & $\begin{array}{c}\text { Top of } \\
\text { Casing } \\
\text { Elevation }\end{array}$ & $\begin{array}{c}\text { Water } \\
\text { Elevation }\end{array}$ \\
\hline & & $(\mathrm{ft})$ & (msl) & (msl) \\
\hline 07/08/94 09:00 & $60-1 B$ & 13.24 & 929.80 & 916.56 \\
\hline $07 / 11 / 9410: 00$ & 60-1B & 13.29 & 929.80 & 916.51 \\
\hline $07 / 12 / 9411: 00$ & $60-1 \mathrm{~B}$ & 13.10 & 929.80 & 916.70 \\
\hline $07 / 15 / 9415: 00$ & $60-1 \mathrm{~B}$ & 13.06 & 929.80 & 916.74 \\
\hline $07 / 19 / 9412: 00$ & $60-1 B$ & 12.72 & 929.80 & 917.08 \\
\hline $07 / 26 / 9409: 00$ & $60-1 B$ & 13.30 & 929.80 & 916.50 \\
\hline $07 / 27 / 9412: 00$ & $60-1 B$ & 12.94 & 929.80 & 916.86 \\
\hline $07 / 29 / 9409: 32$ & $60-1 B$ & 12.41 & 929.80 & 917.39 \\
\hline $07 / 29 / 9412: 39$ & $60-1 \mathrm{~B}$ & 12.47 & 929.80 & 917.33 \\
\hline $07 / 29 / 9414: 14$ & $60-1 B$ & 12.52 & 929.80 & 917.28 \\
\hline $07 / 29 / 9416: 06$ & $60-1 B$ & 12.51 & 929.80 & 917.29 \\
\hline $07 / 29 / 9418: 01$ & $60-1 B$ & 12.54 & 929.80 & 917.26 \\
\hline $07 / 29 / 9419: 12$ & $60-1 \mathrm{~B}$ & 12.56 & 929.80 & 917.24 \\
\hline $07 / 29 / 9420: 15$ & $60-1 B$ & 12.58 & 929.80 & 917.22 \\
\hline $07 / 29 / 9421: 04$ & $60-1 B$ & 12.58 & 929.80 & 917.22 \\
\hline $07 / 29 / 9422: 06$ & $60-1 B$ & 12.60 & 929.80 & 917.20 \\
\hline $07 / 30 / 9400: 04$ & $60-1 B$ & 12.62 & 929.80 & 917.18 \\
\hline $07 / 30 / 9402: 02$ & $60-1 B$ & 12.62 & 929.80 & 917.18 \\
\hline $07 / 30 / 9404: 05$ & 60-1B & 12.62 & 929.80 & 917.18 \\
\hline $07 / 30 / 9406: 03$ & 60-1B & 12.65 & 929.80 & 917.15 \\
\hline $07 / 30 / 9408: 06$ & 60-1B & 12.68 & 929.80 & 917.12 \\
\hline $07 / 30 / 9411: 06$ & $60-1 B$ & 12.69 & 929.80 & 917.11 \\
\hline $07 / 30 / 9414: 19$ & $60-1 B$ & 12.69 & 929.80 & 917.11 \\
\hline $07 / 30 / 9417: 15$ & $60-1 B$ & 12.71 & 929.80 & 917.09 \\
\hline $07 / 30 / 9420: 21$ & 60-1B & 12.75 & 929.80 & 917.05 \\
\hline $07 / 30 / 9423: 13$ & $60-1 B$ & 12.80 & 929.80 & 917.00 \\
\hline $07 / 31 / 9402: 34$ & $60-1 B$ & 12.83 & 929.80 & 916.97 \\
\hline $07 / 31 / 9406: 03$ & $60-1 B$ & 12.84 & 929.80 & 916.96 \\
\hline $07 / 31 / 9409: 01$ & $60-1 B$ & 12.86 & 929.80 & 916.94 \\
\hline $07 / 31 / 9412: 06$ & 60-1B & 12.86 & 929.80 & 916.94 \\
\hline $08 / 02 / 9415: 40$ & $60-1 B$ & 13.04 & 929.80 & 916.76 \\
\hline $06 / 23 / 9416: 30$ & $60-2 A$ & 10.60 & 929.70 & 919.10 \\
\hline $06 / 27 / 9408: 00$ & $60-2 A$ & 10.04 & 929.70 & 919.66 \\
\hline $06 / 28 / 9415: 00$ & $60-2 A$ & 10.30 & 929.70 & 919.40 \\
\hline $07 / 07 / 9416: 00$ & $60-2 A$ & 10.75 & 929.70 & 918.95 \\
\hline 07/08/94 09:00 & $60-2 A$ & 10.70 & 929.70 & 919.00 \\
\hline $07 / 11 / 9410: 00$ & $60-2 A$ & 10.76 & 929.70 & 918.94 \\
\hline $07 / 12 / 9411: 00$ & $60-2 A$ & 10.63 & 929.70 & 919.07 \\
\hline $07 / 15 / 9415: 00$ & $60-2 A$ & 10.63 & 929.70 & 919.07 \\
\hline $07 / 19 / 9412: 00$ & $60-2 A$ & 10.57 & 929.70 & 919.13 \\
\hline $07 / 26 / 9409: 00$ & $60-2 A$ & 10.77 & 929.70 & 918.93 \\
\hline $07 / 27 / 9412: 00$ & $60-2 A$ & 10.50 & 929.70 & 919.20 \\
\hline $07 / 29 / 9409: 40$ & $60-2 A$ & 10.45 & 929.70 & 919.25 \\
\hline $07 / 29 / 9412: 42$ & $60-2 A$ & 10.57 & 929.70 & 919.13 \\
\hline $07 / 29 / 9414: 16$ & $60-2 A$ & 10.55 & 929.70 & 919.15 \\
\hline
\end{tabular}

Page A-4 


\begin{tabular}{|c|c|c|c|c|}
\hline Date / Time & $\begin{array}{c}\text { Well / Sump } \\
\text { ID }\end{array}$ & $\begin{array}{l}\text { Depth To } \\
\text {. Water }\end{array}$ & $\begin{array}{l}\text { Top of } \\
\text { Casing } \\
\text { Elevation }\end{array}$ & $\begin{array}{l}\text { Water } \\
\text { Elevation }\end{array}$ \\
\hline & & (ft) & (msl) & (msl) \\
\hline 07/29/94 16:08 & $60-2 A$ & 10.42 & 929.70 & 919.28 \\
\hline 07/29/94 18:05 & $60-2 A$ & 10.42 & 929.70 & 919.28 \\
\hline $07 / 29 / 9419: 15$ & $60-2 A$ & 10.55 & 929.70 & 919.15 \\
\hline 07/29/94 20:20 & $60-2 A$ & 10.46 & 929.70 & 919.24 \\
\hline $07 / 29 / 9421: 06$ & $60-2 A$ & 10.47 & 929.70 & 919.23 \\
\hline $07 / 29 / 9422: 10$ & $60-2 A$ & 10.59 & 929.70 & 919.11 \\
\hline $07 / 30 / 9400: 05$ & $60-2 A$ & 10.49 & 929.70 & 919.21 \\
\hline $07 / 30 / 9402: 04$ & $60-2 A$ & 10.34 & 929.70 & 919.36 \\
\hline $07 / 30 / 9404: 07$ & $60-2 A$ & 10.48 & 929.70 & 919.22 \\
\hline $07 / 30 / 9406: 05$ & $60-2 A$ & 10.49 & 929.70 & 919.21 \\
\hline $07 / 30 / 9408: 12$ & $60-2 A$ & 10.50 & 929.70 & 919.20 \\
\hline $07 / 30 / 9411: 11$ & $60-2 A$ & 10.63 & 929.70 & 919.07 \\
\hline $07 / 30 / 9414: 22$ & $60-2 A$ & 10.52 & 929.70 & 919.18 \\
\hline $07 / 30 / 9417: 17$ & $60-2 A$ & 10.47 & 929.70 & 919.23 \\
\hline $07 / 30 / 9420: 25$ & $60-2 A$ & 10.50 & 929.70 & 919.20 \\
\hline $07 / 30 / 9423: 16$ & $60-2 A$ & 10.51 & 929.70 & 919.19 \\
\hline $07 / 31 / 9402: 36$ & $60-2 A$ & 10.50 & 929.70 & 919.20 \\
\hline $07 / 31 / 9406: 05$ & $60-2 A$ & 10.66 & 929.70 & 919.04 \\
\hline 07/31/94 09:03 & $60-2 A$ & 10.68 & 929.70 & 919.02 \\
\hline $07 / 31 / 9412: 11$ & $60-2 A$ & 10.54 & 929.70 & 919.16 \\
\hline $08 / 02 / 9415: 40$ & $60-2 A$ & 10.60 & 929.70 & 919.10 \\
\hline $06 / 28 / 9415: 00$ & GW 193 & 7.48 & 934.00 & 926.52 \\
\hline $07 / 08 / 9409: 00$ & GW 193 & 8.35 & 934.00 & 925.65 \\
\hline $07 / 12 / 9411: 00$ & GW 193 & 7.63 & 934.00 & 926.37 \\
\hline $07 / 15 / 9412: 00$ & GW 193 & 7.55 & 934.00 & 926.45 \\
\hline $07 / 27 / 9412: 00$ & GW 193 & 7.18 & 934.00 & 926.82 \\
\hline $07 / 29 / 9410: 58$ & GW 193 & 7.41 & 934.00 & 926.59 \\
\hline $07 / 29 / 9414: 55$ & GW 193 & 7.44 & 934.00 & 926.56 \\
\hline $07 / 29 / 9419: 00$ & GW 193 & 7.49 & 934.00 & 926.51 \\
\hline $07 / 29 / 9422: 59$ & GW 193 & 7.53 & 934.00 & 926.47 \\
\hline $07 / 30 / 9409: 16$ & GW 193 & 7.75 & 934.00 & 926.25 \\
\hline $07 / 30 / 9415: 08$ & GW 193 & 7.80 & 934.00 & 926.20 \\
\hline $07 / 30 / 9417: 55$ & GW 193 & 7.82 & 934.00 & 926.18 \\
\hline $07 / 30 / 9421: 14$ & GW 193 & 7.72 & 934.00 & 926.28 \\
\hline $07 / 30 / 9423: 59$ & GW 193 & 7.76 & 934.00 & 926.24 \\
\hline $07 / 31 / 9402: 59$ & GW 193 & 7.92 & 934.00 & 926.08 \\
\hline $07 / 31 / 9406: 27$ & GW 193 & 7.83 & 934.00 & 926.17 \\
\hline $08 / 02 / 9415: 40$ & GW 193 & 8.15 & 934.00 & 925.85 \\
\hline $06 / 28 / 9415: 00$ & GW 657 & 5.52 & 930.53 & 925.01 \\
\hline $07 / 08 / 9409: 00$ & GW 657 & 6.70 & 930.53 & 923.83 \\
\hline $07 / 12 / 9411: 00$ & GW 657 & 6.38 & 930.53 & 924.15 \\
\hline $07 / 19 / 9412: 00$ & GW 657 & 5.71 & 930.53 & 924.82 \\
\hline $07 / 27 / 9412: 00$ & GW 657 & 6.42 & 930.53 & 924.11 \\
\hline $07 / 29 / 9410: 33$ & GW 657 & 5.79 & 930.53 & 924.74 \\
\hline $07 / 29 / 9414: 44$ & GW 657 & 5.99 & 930.53 & 924.54 \\
\hline
\end{tabular}




\begin{tabular}{|c|c|c|c|c|}
\hline Date / Time & $\begin{array}{c}\text { Well / Sump } \\
\text { ID }\end{array}$ & $\begin{array}{c}\text { Depth To } \\
\text { Water }\end{array}$ & $\begin{array}{l}\text { Top Of } \\
\text { Casing } \\
\text { Elevation }\end{array}$ & $\begin{array}{l}\text { Water } \\
\text { Elevation }\end{array}$ \\
\hline & & . (ft) & (msl) & (msl) \\
\hline $07 / 29 / 9418: 52$ & GW 657 & 6.03 & 930.53 & 924.50 \\
\hline $07 / 29 / 9422: 54$ & GW 657 & 6.17 & 930.53 & 924.36 \\
\hline $07 / 30 / 9409: 04$ & GW 657 & 6.19 & 930.53 & 924.34 \\
\hline $07 / 30 / 94 \quad 15: 01$ & GW 657 & 6.38 & 930.53 & 924.15 \\
\hline $07 / 30 / 9417: 50$ & GW 657 & 6.40 & 930.53 & 924.13 \\
\hline $07 / 30 / 9421: 03$ & GW 657 & 6.43 & 930.53 & 924.10 \\
\hline $07 / 30 / 9423: 53$ & GW 657 & 6.25 & 930.53 & 924.28 \\
\hline $07 / 31 / 9402: 58$ & GW 657 & 6.30 & 930.53 & 924.23 \\
\hline $07 / 31 / 9406: 24$ & GW 657 & 6.11 & 930.53 & 924.42 \\
\hline $08 / 02 / 9415: 40$ & GW 657 & 6.80 & 930.53 & 923.73 \\
\hline $06 / 28 / 9415: 00$ & GW 707 & 9.00 & 930.91 & 921.91 \\
\hline 07/08/94 09:00 & GW 707 & 5.97 & 930.91 & 924.94 \\
\hline $07 / 12 / 9411: 00$ & GW 707 & 10.59 & 930.91 & 920.32 \\
\hline $07 / 19 / 9412: 00$ & GW 707 & 5.50 & 930.91 & 925.41 \\
\hline $07 / 27 / 9412: 00$ & GW 707 & 5.95 & 930.91 & 924.96 \\
\hline $07 / 29 / 94 \quad 10: 51$ & GW 707 & 5.65 & 930.91 & 925.26 \\
\hline $07 / 29 / 9414: 50$ & GW 707 & 5.64 & 930.91 & 925.27 \\
\hline $07 / 29 / 9418: 55$ & GW 707 & 5.65 & 930.91 & 925.26 \\
\hline $07 / 29 / 9422: 56$ & GW 707 & 5.67 & 930.91 & 925.24 \\
\hline $07 / 30 / 9409: 01$ & GW 707 & 5.73 & 930.91 & 925.18 \\
\hline $07 / 30 / 9415: 04$ & GW 707 & 5.75 & 930.91 & 925.16 \\
\hline $07 / 30 / 9417: 52$ & GW 707 & 5.75 & 930.91 & 925.16 \\
\hline $07 / 30 / 9421: 06$ & GW 707 & 5.75 & 930.91 & 925.16 \\
\hline $07 / 30 / 9423: 52$ & GW 707 & 5.74 & 930.91 & 925.17 \\
\hline $07 / 31 / 9402: 56$ & GW 707 & 5.91 & 930.91 & 925.00 \\
\hline $07 / 31 / 9406: 26$ & GW 707 & 5.72 & 930.91 & 925.19 \\
\hline $08 / 02 / 9415: 40$ & GW 707 & 5.98 & 930.91 & 924.93 \\
\hline $06 / 28 / 9415: 00$ & GW 708 & 4.22 & 930.87 & 926.65 \\
\hline $07 / 08 / 9409: 00$ & GW 708 & 4.74 & 930.87 & 926.13 \\
\hline $07 / 12 / 9411: 00$ & GW 708 & 4.52 & 930.87 & 926.35 \\
\hline $07 / 15 / 9412: 00$ & GW 708 & 4.77 & 930.87 & 926.10 \\
\hline $07 / 27 / 9412: 00$ & GW 708 & 4.45 & 930.87 & 926.42 \\
\hline $07 / 29 / 9410: 55$ & GW 708 & 4.23 & 930.87 & 926.64 \\
\hline $07 / 29 / 9414: 52$ & GW 708 & 4.52 & 930.87 & 926.35 \\
\hline $07 / 29 / 9418: 58$ & GW 708 & 4.27 & 930.87 & 926.60 \\
\hline $07 / 29 / 9422: 57$ & GW 708 & 4.28 & 930.87 & 926.59 \\
\hline $07 / 30 / 9409: 13$ & GW 708 & 4.32 & 930.87 & 926.55 \\
\hline $07 / 30 / 9415: 11$ & GW 708 & 4.36 & 930.87 & 926.51 \\
\hline $07 / 30 / 9417: 54$ & GW 708 & 4.35 & 930.87 & 926.52 \\
\hline $07 / 30 / 9421: 09$ & GW 708 & 4.36 & 930.87 & 926.51 \\
\hline $07 / 31 / 9400: 03$ & GW 708 & 4.37 & 930.87 & 926.50 \\
\hline $07 / 31 / 9403: 02$ & GW 708 & 4.39 & 930.87 & 926.48 \\
\hline $07 / 31 / 9406: 29$ & GW 708 & 4.40 & 930.87 & 926.47 \\
\hline $08 / 02 / 9415: 40$ & GW 708 & 4.48 & 930.87 & 926.39 \\
\hline $06 / 28 / 9415: 00$ & GW 769 & 9.20 & 944.26 & 935.06 \\
\hline
\end{tabular}




\begin{tabular}{|c|c|c|c|c|}
\hline Date / Time & $\begin{array}{c}\text { Well / Sump } \\
\text { ID }\end{array}$ & $\begin{array}{l}\text { Depth To } \\
\text {. Water }\end{array}$ & $\begin{array}{c}\text { Top Of } \\
\text { Casing } \\
\text { Elevation }\end{array}$ & $\begin{array}{l}\text { Water } \\
\text { Elevation }\end{array}$ \\
\hline & & (ft) & (msl) & (msl) \\
\hline 07/08/94 09:00 & GW 769 & 11.77 & 944.26 & 932.49 \\
\hline $07 / 12 / 9411: 00$ & GW 769 & 10.63 & 944.26 & 933.63 \\
\hline $07 / 19 / 9412: 00$ & GW 769 & 8.65 & 944.26 & 935.61 \\
\hline $07 / 26 / 9409: 00$ & GW 769 & 11.58 & 944.26 & 932.68 \\
\hline $07 / 27 / 9412: 00$ & GW 769 & 9.99 & 944.26 & 934.27 \\
\hline $07 / 29 / 9410: 00$ & GW 769 & 8.89 & 944.26 & 935.37 \\
\hline $07 / 29 / 9414: 25$ & GW 769 & 9.03 & 944.26 & 935.23 \\
\hline $07 / 29 / 9418: 24$ & GW 769 & 9.16 & 944.26 & 935.10 \\
\hline $07 / 29 / 9422: 30$ & GW 769 & 9.34 & 944.26 & 934.92 \\
\hline $07 / 30 / 9408: 36$ & GW 769 & 9.85 & 944.26 & 934.41 \\
\hline $07 / 30 / 9411: 29$ & GW 769 & 9.81 & 944.26 & 934.45 \\
\hline $07 / 30 / 9414: 40$ & GW 769 & 9.91 & 944.26 & 934.35 \\
\hline $07 / 30 / 9417: 33$ & GW 769 & 9.97 & 944.26 & 934.29 \\
\hline $07 / 30 / 9420: 43$ & GW 769 & 10.01 & 944.26 & 934.25 \\
\hline $07 / 30 / 9423: 35$ & GW 769 & 10.12 & 944.26 & 934.14 \\
\hline $07 / 31 / 9402: 49$ & GW 769 & 10.23 & 944.26 & 934.03 \\
\hline $07 / 31 / 9406: 14$ & GW 769 & 10.35 & 944.26 & 933.91 \\
\hline $08 / 02 / 9415: 40$ & GW 769 & 11.16 & 944.26 & 933.10 \\
\hline $06 / 28 / 9415: 00$ & GW 770 & 11.50 & 944.55 & 933.05 \\
\hline $07 / 08 / 9409: 00$ & GW 770 & 14.15 & 944.55 & 930.40 \\
\hline $07 / 12 / 9411: 00$ & GW 770 & 13.00 & 944.55 & 931.55 \\
\hline $07 / 19 / 9412: 00$ & GW 770 & 10.85 & 944.55 & 933.70 \\
\hline $07 / 26 / 9409: 00$ & GW 770 & 14.23 & 944.55 & 930.32 \\
\hline $07 / 27 / 9412: 00$ & GW 770 & 11.65 & 944.55 & 932.90 \\
\hline $07 / 29 / 9410: 03$ & GW 770 & 11.31 & 944.55 & 933.24 \\
\hline $07 / 29 / 9414: 28$ & GW 770 & 11.57 & 944.55 & 932.98 \\
\hline $07 / 29 / 9418: 34$ & GW 770 & 11.75 & 944.55 & 932.80 \\
\hline $07 / 29 / 9422: 34$ & GW 770 & 11.96 & 944.55 & 932.59 \\
\hline $07 / 30 / 9408: 34$ & GW 770 & 12.40 & 944.55 & 932.15 \\
\hline $07 / 30 / 9411: 26$ & GW 770 & 12.49 & 944.55 & 932.06 \\
\hline $07 / 30 / 9414: 36$ & GW 770 & 12.55 & 944.55 & 932.00 \\
\hline $07 / 30 / 9417: 35$ & GW 770 & 12.61 & 944.55 & 931.94 \\
\hline $07 / 30 / 9420: 46$ & GW 770 & 12.67 & 944.55 & 931.88 \\
\hline $07 / 30 / 9423: 34$ & GW 770 & 12.61 & 944.55 & 931.94 \\
\hline $07 / 31 / 9402: 48$ & GW 770 & 12.78 & 944.55 & 931.77 \\
\hline $07 / 31 / 9406: 12$ & GW 770 & 12.84 & 944.55 & 931.71 \\
\hline $08 / 02 / 9415: 40$ & GW 770 & 13.47 & 944.55 & 931.08 \\
\hline $06 / 28 / 9415: 00$ & GW 810 & 9.17 & 931.44 & 922.27 \\
\hline 07/08/94 09:00 & GW 810 & 9.07 & 931.44 & 922.37 \\
\hline $07 / 12 / 9411: 00$ & GW 810 & 8.85 & 931.44 & 922.59 \\
\hline $07 / 19 / 9412: 00$ & GW 810 & 8.83 & 931.44 & 922.61 \\
\hline $07 / 27 / 9412: 00$ & GW 810 & 8.74 & 931.44 & 922.70 \\
\hline $07 / 29 / 9410: 22$ & GW 810 & 8.33 & 931.44 & 923.11 \\
\hline $07 / 29 / 9414: 41$ & GW 810 & 8.51 & 931.44 & 922.93 \\
\hline $07 / 29 / 9418: 47$ & GW 810 & 8.45 & 931.44 & 922.99 \\
\hline
\end{tabular}




\begin{tabular}{|c|c|c|c|c|}
\hline Date / Time & $\begin{array}{c}\text { Well / Sump } \\
\text { ID }\end{array}$ & $\begin{array}{c}\text { Depth To } \\
\text { Water }\end{array}$ & $\begin{array}{l}\text { Top Of } \\
\text { Casing } \\
\text { Elevation }\end{array}$ & $\begin{array}{l}\text { Water } \\
\text { Elevation }\end{array}$ \\
\hline & & (ft) & (msl) & (msl) \\
\hline $07 / 29 / 9422: 50$ & GW 810 & 8.53 & 931.44 & 922.91 \\
\hline 07/30/94 08:57 & GW 810 & 8.60 & 931.44 & 922.84 \\
\hline $07 / 30 / 9414: 58$ & GW 810 & 8.67 & 931.44 & 922.77 \\
\hline $07 / 30 / 9417: 48$ & GW 810 & 8.69 & 931.44 & 922.75 \\
\hline $07 / 30 / 9421: 00$ & GW 810 & 8.70 & 931.44 & 922.74 \\
\hline $08 / 02 / 9415: 40$ & GW 810 & 8.68 & 931.44 & 922.76 \\
\hline $06 / 28 / 9415: 00$ & GW 818 & 8.90 & 927.92 & 919.02 \\
\hline $07 / 07 / 9416: 00$ & GW 818 & 9.12 & 927.92 & 918.80 \\
\hline $07 / 08 / 9409: 00$ & GW 818 & 9.17 & 927.92 & 918.75 \\
\hline $07 / 12 / 9411: 00$ & GW 818 & 9.00 & 927.92 & 918.92 \\
\hline $07 / 15 / 9415: 00$ & GW 818 & 9.15 & 927.92 & 918.77 \\
\hline $07 / 19 / 9412: 00$ & GW 818 & 8.96 & 927.92 & 918.96 \\
\hline $07 / 26 / 9409: 00$ & GW 818 & 9.03 & 927.92 & 918.89 \\
\hline $07 / 27 / 9412: 00$ & GW 818 & 8.93 & 927.92 & 918.99 \\
\hline $07 / 29 / 9409: 43$ & GW 818 & 8.98 & 927.92 & 918.94 \\
\hline $07 / 29 / 9412: 44$ & GW 818 & 9.09 & 927.92 & 918.83 \\
\hline $07 / 29 / 9414: 17$ & GW 818 & 8.95 & 927.92 & 918.97 \\
\hline $07 / 29 / 9416: 10$ & GW 818 & 8.93 & 927.92 & 918.99 \\
\hline $07 / 29 / 9418: 06$ & GW 818 & 8.98 & 927.92 & 918.94 \\
\hline $07 / 29 / 9419: 18$ & GW 818 & 8.97 & 927.92 & 918.95 \\
\hline $07 / 29 / 9420: 24$ & GW 818 & 8.97 & 927.92 & 918.95 \\
\hline $07 / 29 / 9421: 09$ & GW 818 & 8.98 & 927.92 & 918.94 \\
\hline $07 / 29 / 9422: 13$ & GW 818 & 9.04 & 927.92 & 918.88 \\
\hline 07/30/94 00:07 & GW 818 & 8.98 & 927.92 & 918.94 \\
\hline $07 / 30 / 9402: 06$ & GW 818 & 8.97 & 927.92 & 918.95 \\
\hline $07 / 30 / 9404: 08$ & GW 818 & 8.97 & 927.92 & 918.95 \\
\hline $07 / 30 / 9406: 06$ & GW 818 & 8.96 & 927.92 & 918.96 \\
\hline $07 / 30 / 9408: 15$ & GW 818 & 8.97 & 927.92 & 918.95 \\
\hline $07 / 30 / 94 \quad 11: 14$ & GW 818 & 8.97 & 927.92 & 918.95 \\
\hline $07 / 30 / 9414: 24$ & GW 818 & 8.98 & 927.92 & 918.94 \\
\hline $07 / 30 / 94 \quad 17: 19$ & GW 818 & 8.99 & 927.92 & 918.93 \\
\hline $07 / 30 / 9420: 28$ & GW 818 & 8.98 & 927.92 & 918.94 \\
\hline $07 / 30 / 9423: 24$ & GW 818 & 8.98 & 927.92 & 918.94 \\
\hline 07/31/94 02:38 & GW 818 & 8.99 & 927.92 & 918.93 \\
\hline $07 / 31 / 9406: 06$ & GW 818 & 9.00 & 927.92 & 918.92 \\
\hline $07 / 31 / 9409: 05$ & GW 818 & 8.95 & 927.92 & 918.97 \\
\hline $07 / 31 / 94 \quad 12: 14$ & GW 818 & 9.12 & 927.92 & 918.80 \\
\hline $08 / 02 / 9415: 40$ & GW 818 & 9.14 & 927.92 & 918.78 \\
\hline $06 / 23 / 9416: 30$ & GW 819 & 9.91 & 928.75 & 918.84 \\
\hline $06 / 27 / 9408: 00$ & GW 819 & 9.20 & 928.75 & 919.55 \\
\hline $06 / 28 / 9415: 00$ & GW 819 & 9.40 & 928.75 & 919.35 \\
\hline $07 / 07 / 9416: 00$ & GW 819 & 9.84 & 928.75 & 918.91 \\
\hline $07 / 08 / 9409: 00$ & GW 819 & 9.71 & 928.75 & 919.04 \\
\hline $07 / 12 / 9411: 00$ & GW 819 & 9.79 & 928.75 & 918.96 \\
\hline $07 / 15 / 9415: 00$ & GW 819 & 9.76 & 928.75 & 918.99 \\
\hline
\end{tabular}




\begin{tabular}{|c|c|c|c|c|}
\hline Date / Time & $\begin{array}{c}\text { Well / Sump } \\
\text { ID }\end{array}$ & $\begin{array}{l}\text { Depth To } \\
\text { - Water }\end{array}$ & $\begin{array}{c}\text { Top of } \\
\text { Casing } \\
\text { Elevation }\end{array}$ & $\begin{array}{l}\text { Water } \\
\text { Elevation }\end{array}$ \\
\hline & & (ft) & (msl) & (msl) \\
\hline 07/19/94 12:00 & GW 819 & 9.54 & 928.75 & 919.21 \\
\hline $07 / 26 / 9409: 00$ & GW 819 & 9.88 & 928.75 & 918.87 \\
\hline $07 / 27 / 9412: 00$ & GW 819 & 9.79 & 928.75 & 918.96 \\
\hline 07/29/94 09:48 & GW 819 & 9.33 & 928.75 & 919.42 \\
\hline $07 / 29 / 9412: 46$ & GW 819 & 9.24 & 928.75 & 919.51 \\
\hline $07 / 29 / 9418: 10$ & GW 819 & 9.40 & 928.75 & 919.35 \\
\hline $07 / 29 / 9419: 22$ & GW 819 & 9.42 & 928.75 & 919.33 \\
\hline $07 / 29 / 9420: 27$ & GW 819 & 9.43 & 928.75 & 919.32 \\
\hline $07 / 29 / 9421: 12$ & GW 819 & 9.44 & 928.75 & 919.31 \\
\hline $07 / 29 / 9422: 16$ & GW 819 & 9.57 & 928.75 & 919.18 \\
\hline $07 / 30 / 9400: 10$ & GW 819 & 9.46 & 928.75 & 919.29 \\
\hline $07 / 30 / 9402: 09$ & GW 819 & 9.48 & 928.75 & 919.27 \\
\hline 07/30/94 04:11 & GW 819 & 9.50 & 928.75 & 919.25 \\
\hline $07 / 30 / 9406: 08$ & GW 819 & 9.50 & 928.75 & 919.25 \\
\hline $07 / 30 / 9408: 20$ & GW 819 & 9.56 & 928.75 & 919.19 \\
\hline $07 / 30 / 9411: 17$ & GW 819 & 9.55 & 928.75 & 919.20 \\
\hline $07 / 30 / 9414: 27$ & GW 819 & 9.57 & 928.75 & 919.18 \\
\hline $07 / 30 / 9417: 21$ & GW 819 & 9.56 & 928.75 & 919.19 \\
\hline $07 / 30 / 9420: 30$ & GW 819 & 9.59 & 928.75 & 919.16 \\
\hline $07 / 30 / 9423: 22$ & GW 819 & 9.60 & 928.75 & 919.15 \\
\hline $07 / 31 / 9402: 41$ & GW 819 & 9.61 & 928.75 & 919.14 \\
\hline 07/31/94 06:07 & GW 819 & 9.61 & 928.75 & 919.14 \\
\hline 07/31/94 09:07 & GW 819 & 9.63 & 928.75 & 919.12 \\
\hline $07 / 31 / 9412: 16$ & GW 819 & 9.65 & 928.75 & 919.10 \\
\hline $08 / 02 / 9415: 40$ & GW 819 & 9.72 & 928.75 & 919.03 \\
\hline $06 / 27 / 9408: 00$ & GW 820 & 9.38 & 929.56 & 920.18 \\
\hline $06 / 28 / 9415: 00$ & GW 820 & 9.60 & 929.56 & 919.96 \\
\hline $07 / 07 / 9416: 00$ & GW 820 & 10.14 & 929.56 & 919.42 \\
\hline 07/08/94 09:00 & GW 820 & 10.08 & 929.56 & 919.48 \\
\hline $07 / 12 / 9411: 00$ & GW 820 & 10.03 & 929.56 & 919.53 \\
\hline 07/15/94 15:00. & GW 820 & 9.91 & 929.56 & 919.65 \\
\hline $07 / 19 / 9412: 00$ & GW 820 & 9.75 & 929.56 & 919.81 \\
\hline $07 / 26 / 9409: 00$ & GW 820 & 10.03 & 929.56 & 919.53 \\
\hline $07 / 27 / 9412: 00$ & GW 820 & 9.95 & 929.56 & 919.61 \\
\hline $07 / 29 / 9409: 53$ & GW 820 & 9.61 & 929.56 & 919.95 \\
\hline $07 / 29 / 9412: 51$ & GW 820 & 9.60 & 929.56 & 919.96 \\
\hline $07 / 29 / 9414: 21$ & GW 820 & 9.63 & 929.56 & 919.93 \\
\hline $07 / 29 / 9416: 14$ & GW 820 & 9.57 & 929.56 & 919.99 \\
\hline $07 / 29 / 9418: 15$ & GW 820 & 9.65 & 929.56 & 919.91 \\
\hline $07 / 29 / 9419: 25$ & GW 820 & 9.65 & 929.56 & 919.91 \\
\hline 07/29/94 20:30 & GW 820 & 9.66 & 929.56 & 919.90 \\
\hline $07 / 29 / 9421: 17$ & GW 820 & 9.66 & 929.56 & 919.90 \\
\hline $07 / 29 / 9422: 22$ & GW 820 & 9.67 & 929.56 & 919.89 \\
\hline $07 / 30 / 9400: 12$ & GW 820 & 9.69 & 929.56 & 919.87 \\
\hline $07 / 30 / 9402: 11$ & GW 820 & 9.69 & 929.56 & 919.87 \\
\hline
\end{tabular}




\begin{tabular}{|c|c|c|c|c|}
\hline Date / Time & $\begin{array}{c}\text { Well / Sump } \\
\text { ID }\end{array}$ & $\begin{array}{c}\text { Depth To } \\
\text { Water }\end{array}$ & $\begin{array}{c}\text { Top Of } \\
\text { Casing } \\
\text { Elevation }\end{array}$ & $\begin{array}{c}\text { Water } \\
\text { Elevation }\end{array}$ \\
\hline & & (ft) & $(m s l)$ & (msI) \\
\hline $07 / 30 / 9404: 14$ & GW 820 & 9.70 & 929.56 & 919.86 \\
\hline $07 / 30 / 9406: 10$ & GW 820 & 9.71 & 929.56 & 919.85 \\
\hline $07 / 30 / 9408: 26$ & GW 820 & 9.73 & 929.56 & 919.83 \\
\hline $07 / 30 / 9411: 19$ & GW 820 & 9.72 & 929.56 & 919.84 \\
\hline $07 / 30 / 9414: 30$ & GW 820 & 9.74 & 929.56 & 919.82 \\
\hline $07 / 30 / 9417: 26$ & GW 820 & 9.76 & 929.56 & 919.80 \\
\hline $07 / 30 / 9420: 36$ & GW 820 & 9.73 & 929.56 & 919.83 \\
\hline $07 / 30 / 9423: 27$ & GW 820 & 9.78 & 929.56 & 919.78 \\
\hline $07 / 31 / 9402: 44$ & GW 820 & 9.81 & 929.56 & 919.75 \\
\hline $07 / 31 / 9406: 10$ & GW 820 & 9.80 & 929.56 & 919.76 \\
\hline $07 / 31 / 9409: 09$ & GW 820 & 9.82 & 929.56 & 919.74 \\
\hline $07 / 31 / 9412: 25$ & GW 820 & 9.84 & 929.56 & 919.72 \\
\hline $08 / 02 / 94 \quad 15: 40$ & GW 820 & 9.94 & 929.56 & 919.62 \\
\hline $07 / 29 / 9412: 20$ & E13 Sump & 1.41 & 917.87 & 916.46 \\
\hline 07/29/94 13:40 & E13 Sump & 1.29 & 917.87 & 916.58 \\
\hline $07 / 29 / 9414: 38$ & E13 Sump & 1.21 & 917.87 & 916.66 \\
\hline $07 / 29 / 9415: 42$ & E13 Sump & 1.10 & 917.87 & 916.77 \\
\hline $07 / 29 / 9416: 42$ & E13 Sump & 1.01 & 917.87 & 916.86 \\
\hline $07 / 29 / 9417: 43$ & E13 Sump & 0.94 & 917.87 & 916.93 \\
\hline $07 / 29 / 9418: 39$ & E13 Sump & 0.93 & 917.87 & 916.94 \\
\hline $07 / 29 / 9419: 39$ & E13 Sump & 0.92 & 917.87 & 916.95 \\
\hline $07 / 29 / 9420: 40$ & E13 Sump & 0.92 & 917.87 & 916.95 \\
\hline $07 / 29 / 9421: 40$ & E13 Sump & 0.92 & 917.87 & 916.95 \\
\hline $07 / 29 / 9422: 41$ & E13 Sump & 0.92 & 917.87 & 916.95 \\
\hline $07 / 29 / 9423: 46$ & E13 Sump & 0.92 & 917.87 & 916.95 \\
\hline $07 / 30 / 9400: 51$ & E13 Sump & 0.91 & 917.87 & 916.96 \\
\hline $07 / 30 / 9401: 44$ & E13 Sump & 0.90 & 917.87 & 916.97 \\
\hline $07 / 30 / 9402: 49$ & E13 Sump & 0.91 & 917.87 & 916.96 \\
\hline $07 / 30 / 9403: 55$ & E13 Sump & 0.91 & 917.87 & 916.96 \\
\hline $07 / 30 / 9404: 48$ & E13 Sump & 0.90 & 917.87 & 916.97 \\
\hline $07 / 30 / 9405: 46$ & E13 Sump & 0.92 & 917.87 & 916.95 \\
\hline $07 / 30 / 9406: 49$ & E13 Sump & 0.90 & 917.87 & 916.97 \\
\hline $07 / 30 / 9407: 43$ & E13 Sump & 0.91 & 917.87 & 916.96 \\
\hline $07 / 30 / 9408: 43$ & E13 Sump & 0.91 & 917.87 & 916.96 \\
\hline $07 / 30 / 9409: 40$ & E13 Sump & 0.91 & 917.87 & 916.96 \\
\hline $07 / 30 / 9410: 40$ & E13 Sump & 0.90 & 917.87 & 916.97 \\
\hline $07 / 30 / 9411: 42$ & E13 Sump & 0.90 & 917.87 & 916.97 \\
\hline $07 / 30 / 9412: 39$ & E13 Sump & 0.91 & 917.87 & 916.96 \\
\hline $07 / 30 / 9413: 48$ & E13 Sump & 0.91 & 917.87 & 916.96 \\
\hline $07 / 30 / 9414: 43$ & E13 Sump & 0.91 & 917.87 & 916.96 \\
\hline $07 / 30 / 9416: 46$ & E13 Sump & 0.91 & $917 . \overline{87}$ & $9 \overline{916.96}$ \\
\hline $07 / 30 / 9418: 49$ & E13 Sump & 0.90 & 917.87 & 916.97 \\
\hline $07 / 30 / 9420: 45$ & E13 Sump & 0.90 & 917.87 & 916.97 \\
\hline $07 / 30 / 9422: 44$ & E13 Sump & 0.90 & 917.87 & 916.97 \\
\hline $07 / 31 / 9400: 47$ & E13 Sump & 0.90 & 917.87 & 916.97 \\
\hline
\end{tabular}




\begin{tabular}{|c|c|c|c|c|}
\hline Date / Time & $\begin{array}{c}\text { Well / Sump } \\
\text { ID }\end{array}$ & $\begin{array}{l}\text { Depth To } \\
\text { - Water }\end{array}$ & $\begin{array}{l}\text { Top Of } \\
\text { Casing } \\
\text { Elevation }\end{array}$ & $\begin{array}{l}\text { Water } \\
\text { Elevation }\end{array}$ \\
\hline & & (ft) & (msl) & (msl) \\
\hline $07 / 31 / 9402: 51$ & E13 Sump & 0.89 & 917.87 & 916.98 \\
\hline $07 / 31 / 9404: 41$ & E13 Sump & 0.89 & 917.87 & 916.98 \\
\hline $07 / 31 / 9406: 46$ & E13 Sump & 0.89 & 917.87 & 916.98 \\
\hline $07 / 07 / 9415: 50$ & E22 Sump & 2.75 & 918.21 & 915.46 \\
\hline $07 / 29 / 9412: 10$ & E22 Sump & 3.20 & 918.57 & 915.38 \\
\hline $07 / 29 / 9413: 45$ & E22 Sump & 3.19 & 918.57 & 915.38 \\
\hline $07 / 29 / 9414: 46$ & E22 Sump & 3.20 & 918.57 & 915.37 \\
\hline $07 / 29 / 9415: 46$ & E22 Sump & 3.18 & 918.57 & 915.39 \\
\hline $07 / 29 / 9416: 45$ & E22 Sump & 3.17 & 918.57 & 915.40 \\
\hline $07 / 29 / 9417: 46$ & E22 Sump & 3.18 & 918.57 & 915.39 \\
\hline $07 / 29 / 9418: 44$ & E22 Sump & 3.17 & 918.57 & 915.40 \\
\hline $07 / 29 / 9419: 45$ & E22 Sump & 3.15 & 918.57 & 915.42 \\
\hline 07/29/94 20:44 & E22 Sump & 3.15 & 918.57 & 915.42 \\
\hline $07 / 29 / 9421: 44$ & E22 Sump & 3.15 & 918.57 & 915.42 \\
\hline $07 / 29 / 9422: 44$ & E22 Sump & 3.15 & 918.57 & 915.42 \\
\hline $07 / 29 / 9423: 54$ & E22 Sump & 3.11 & 918.57 & 915.46 \\
\hline $07 / 30 / 9400: 54$ & E22 Sump & 3.10 & 918.57 & 915.47 \\
\hline $07 / 30 / 9401: 48$ & E22 Sump & 3.09 & 918.57 & 915.48 \\
\hline $07 / 30 / 9402: 53$ & E22 Sump & 3.08 & 918.57 & 915.49 \\
\hline $07 / 30 / 9404: 00$ & E22 Sump & 3.07 & 918.57 & 915.50 \\
\hline $07 / 30 / 9404: 52$ & E22 Sump & 3.06 & 918.57 & 915.51 \\
\hline $07 / 30 / 9405: 48$ & E22 Sump & 3.05 & 918.57 & 915.52 \\
\hline $07 / 30 / 9406: 52$ & E22 Sump & 3.04 & 918.57 & 915.53 \\
\hline $07 / 30 / 9407: 47$ & E22 Sump & 3.05 & 918.57 & 915.52 \\
\hline $07 / 30 / 9408: 48$ & E22 Sump & 3.04 & 918.57 & 915.53 \\
\hline $07 / 30 / 9409: 44$ & E22 Sump & 3.04 & 918.57 & 915.53 \\
\hline $07 / 30 / 9410: 45$ & E22 Sump & 3.02 & 918.57 & 915.55 \\
\hline $07 / 30 / 9411: 45$ & E22 Sump & 3.01 & 918.57 & 915.56 \\
\hline $07 / 30 / 9412: 43$ & E22 Sump & 3.00 & 918.57 & 915.57 \\
\hline $07 / 30 / 9413: 51$ & E22 Sump & 2.99 & 918.57 & 915.58 \\
\hline $07 / 30 / 9414: 46$ & E22 Sump & 2.98 & 918.57 & 915.59 \\
\hline $07 / 30 / 9416: 51$ & E22 Sump & 2.95 & 918.57 & 915.62 \\
\hline $07 / 30 / 9418: 53$ & E22 Sump & 2.92 & 918.57 & 915.65 \\
\hline $07 / 30 / 9420: 49$ & E22 Sump & 2.90 & 918.57 & 915.67 \\
\hline $07 / 30 / 9422: 48$ & E22 Sump & 2.88 & 918.57 & 915.69 \\
\hline $07 / 31 / 9400: 51$ & E22 Sump & 2.85 & 918.57 & 915.72 \\
\hline $07 / 31 / 9402: 55$ & E22 Sump & 2.83 & 918.57 & 915.74 \\
\hline $07 / 31 / 9404: 46$ & E22 Sump & 2.82 & 918.57 & 915.75 \\
\hline $07 / 31 / 9406: 49$ & E22 Sump & 2.80 & 918.57 & 915.77 \\
\hline $07 / 30 / 9406: 56$ & F3 Sump & 0.88 & 921.44 & 920.56 \\
\hline $07 / 29 / 9412: 35$ & K22 Pit & 5.81 & 923.50 & 917.69 \\
\hline $07 / 29 / 9413: 52$ & K22 Pit & 5.80 & 923.50 & 917.70 \\
\hline $07 / 29 / 9414: 54$ & K22 Pit & 5.80 & 923.50 & 917.70 \\
\hline $07 / 29 / 9415: 54$ & K22 Pit & 5.81 & 923.50 & 917.69 \\
\hline $07 / 29 / 9416: 53$ & K22 Pit & 5.82 & 923.50 & 917.68 \\
\hline
\end{tabular}




\begin{tabular}{|c|c|c|c|c|}
\hline Date / Time & $\begin{array}{l}\text { Well / Sump } \\
\text { ID }\end{array}$ & $\begin{array}{c}\text { Depth To } \\
\text { Water }\end{array}$ & $\begin{array}{l}\text { Top of } \\
\text { Casing } \\
\text { Elevation }\end{array}$ & $\begin{array}{l}\text { Water } \\
\text { Elevation }\end{array}$ \\
\hline & & $(\mathrm{ft})$ & (msl) & (msi) \\
\hline 07/29/94 17:53 & K22 Pit & 5.81 & 923.50 & 917.69 \\
\hline $07 / 29 / 9418: 51$ & K22 Pit & 5.81 & 923.50 & 917.69 \\
\hline $07 / 29 / 9420: 51$ & K22 Pit & 5.82 & 923.50 & 917.68 \\
\hline $07 / 29 / 9422: 50$ & K22 Pit & 5.81 & 923.50 & 917.69 \\
\hline $07 / 30 / 9401: 07$ & K22 Pit & 5.83 & 923.50 & 917.67 \\
\hline $07 / 30 / 9403: 02$ & K22 Pit & 5.81 & 923.50 & 917.69 \\
\hline $07 / 30 / 9407: 00$ & K22 Pit & 5.82 & 923.50 & 917.68 \\
\hline $07 / 30 / 9414: 57$ & K22 Pit & 5.81 & 923.50 & 917.69 \\
\hline $07 / 30 / 9419: 02$ & K22 Pit & 5.80 & 923.50 & 917.70 \\
\hline $07 / 30 / 9422: 56$ & K22 Pit & 5.80 & 923.50 & 917.70 \\
\hline $07 / 31 / 9406: 59$ & K22 Pit & 5.79 & 923.50 & 917.71 \\
\hline $07 / 07 / 9415: 00$ & 012 Sump & 3.12 & 915.08 & 911.96 \\
\hline $07 / 11 / 9409: 30$ & 012 Sump & 3.13 & 915.08 & 911.95 \\
\hline $07 / 15 / 9414: 00$ & O12 Sump & 3.49 & 915.08 & 911.59 \\
\hline $07 / 20 / 9409: 30$ & 012 Sump & 3.54 & 915.08 & 911.54 \\
\hline $07 / 29 / 9411: 55$ & 012 Sump & 3.45 & 915.08 & 911.63 \\
\hline 07/29/94 13:40 & 012 Sump & 2.75 & 915.08 & 912.33 \\
\hline $07 / 29 / 9414: 33$ & 012 Sump & 2.56 & 915.08 & 912.52 \\
\hline 07/29/94 15:36 & 012 Sump & 2.40 & 915.08 & 912.68 \\
\hline 07/29/94 16:36 & 012 Sump & 2.27 & 915.08 & 912.81 \\
\hline $07 / 29 / 9417: 36$ & 012 Sump & 2.18 & 915.08 & 912.90 \\
\hline 07/29/94 18:34 & O12 Sump & 2.10 & 915.08 & 912.98 \\
\hline 07/29/94 19:31 & 012 Sump & 2.03 & 915.08 & 913.05 \\
\hline $07 / 29 / 9420: 35$ & 012 Sump & 1.97 & 915.08 & 913.11 \\
\hline $07 / 29 / 9421: 35$ & O12 Sump & 1.91 & 915.08 & 913.17 \\
\hline $07 / 29 / 9422: 33$ & 012 Sump & 1.86 & 915.08 & 913.22 \\
\hline $07 / 29 / 9423: 37$ & 012 Sump & 1.80 & 915.08 & 913.28 \\
\hline $07 / 30 / 9400: 42$ & 012 Sump & 1.75 & 915.08 & 913.33 \\
\hline $07 / 30 / 9401: 36$ & 012 Sump & 1.71 & 915.08 & 913.37 \\
\hline $07 / 30 / 9402: 39$ & 012 Sump & 1.67 & 915.08 & 913.41 \\
\hline $07 / 30 / 9403: 42$ & 012 Sump & 1.62 & 915.08 & 913.46 \\
\hline $07 / 30 / 9404: 42$ & 012 Sump & 1.57 & 915.08 & 913.51 \\
\hline $07 / 30 / 9405: 41$ & 012 Sump & 1.54 & 915.08 & 913.54 \\
\hline $07 / 30 / 9406: 43$ & 012 Sump & 1.50 & 915.08 & 913.58 \\
\hline $07 / 30 / 9407: 36$ & 012 Sump & 1.47 & 915.08 & 913.61 \\
\hline $07 / 30 / 9408: 34$ & 012 Sump & 1.44 & 915.08 & 913.64 \\
\hline 07/30/94 09:34 & 012 Sump & 1.42 & 915.08 & 913.66 \\
\hline $07 / 30 / 94 \quad 10: 34$ & 012 Sump & 1.38 & 915.08 & 913.70 \\
\hline $07 / 30 / 9411: 34$ & O12 Sump & 1.34 & 915.08 & 913.74 \\
\hline $07 / 30 / 94 \quad 12: 32$ & 012 Sump & 1.32 & 915.08 & 913.76 \\
\hline $07 / 30 / 9413: 37$ & 012 Sump & 1.29 & 915.08 & 913.79 \\
\hline $07 / 30 / 9414: 35$ & 012 Sump & 1.28 & 915.08 & 913.80 \\
\hline $07 / 30 / 9416: 39$ & O12 Sump & 1.28 & 915.08 & 913.80 \\
\hline $07 / 30 / 9418: 40$ & 012 Sump & 1.25 & 915.08 & 913.83 \\
\hline $07 / 30 / 9420: 38$ & 012 Sump & 1.21 & 915.08 & 913.87 \\
\hline
\end{tabular}




\begin{tabular}{|c|c|c|c|c|}
\hline Date / Time & $\begin{array}{c}\text { Well / Sump } \\
\text { ID }\end{array}$ & $\begin{array}{l}\text { Depth To } \\
\text {-Water }\end{array}$ & $\begin{array}{c}\text { Top Of } \\
\text { Casing } \\
\text { Elevation }\end{array}$ & $\begin{array}{l}\text { Water } \\
\text { Elevation }\end{array}$ \\
\hline & & (ft) & (msl) & (msl) \\
\hline $07 / 30 / 9422: 36$ & 012 Sump & 1.19 & 915.08 & 913.89 \\
\hline $07 / 31 / 9400: 37$ & 012 Sump & 1.15 & 915.08 & 913.93 \\
\hline $07 / 31 / 9402: 35$ & O12 Sump & 1.10 & 915.08 & 913.98 \\
\hline $07 / 31 / 9404: 34$ & 012 Sump & 1.07 & 915.08 & 914.01 \\
\hline $07 / 31 / 9406: 40$ & O12 Sump & 1.03 & 915.08 & 914.05 \\
\hline $07 / 31 / 9409: 18$ & 012 Sump & 1.16 & 915.08 & 913.92 \\
\hline $07 / 31 / 9410: 07$ & 012 Sump & 1.29 & 915.08 & 913.79 \\
\hline $07 / 31 / 9411: 03$ & 012 Sump & 1.54 & 915.08 & 913.54 \\
\hline $07 / 31 / 9412: 07$ & 012 Sump & 1.83 & 915.08 & 913.25 \\
\hline $07 / 31 / 9417: 47$ & 012 Sump & 3.33 & 915.08 & 911.75 \\
\hline $07 / 11 / 9409: 30$ & $012-1$ & DRY & 918.11 & $>912.27$ \\
\hline $07 / 15 / 9414: 00$ & $012-1$ & DRY & 918.11 & $>912.27$ \\
\hline $07 / 20 / 9409: 30$ & $012-1$ & DRY & 918.11 & $>912.27$ \\
\hline $07 / 29 / 9411: 45$ & $012-1$ & DRY & 918.11 & $>912.27$ \\
\hline $07 / 29 / 9413: 30$ & $012-1$ & DRY & 918.11 & $>912.27$ \\
\hline $07 / 29 / 9414: 30$ & $012-1$ & DRY & 918.11 & $>912.27$ \\
\hline $07 / 29 / 9415: 34$ & $012-1$ & DAMP & 918.11 & 912.27 \\
\hline $07 / 29 / 9416: 33$ & $012-1$ & 5.45 & 918.11 & 912.66 \\
\hline $07 / 29 / 94 \quad 17: 32$ & $012-1$ & 5.18 & 918.11 & 912.93 \\
\hline $07 / 29 / 9418: 32$ & $012-1$ & 5.12 & 918.11 & 912.99 \\
\hline $07 / 29 / 9419: 29$ & $012-1$ & 5.05 & 918.11 & 913.07 \\
\hline $07 / 29 / 9420: 32$ & $012-1$ & 4.98 & 918.11 & 913.13 \\
\hline $07 / 29 / 9421: 32$ & $012-1$ & 4.91 & 918.11 & 913.20 \\
\hline $07 / 29 / 9422: 31$ & $012-1$ & 4.88 & 918.11 & 913.23 \\
\hline $07 / 29 / 9423: 33$ & $012-1$ & 4.81 & 918.11 & 913.30 \\
\hline $07 / 30 / 9400: 39$ & $012-1$ & 4.76 & 918.11 & 913.35 \\
\hline $07 / 30 / 9401: 33$ & $012-1$ & 4.72 & 918.11 & 913.39 \\
\hline $07 / 30 / 9402: 37$ & $012-1$ & 4.67 & 918.11 & 913.44 \\
\hline $07 / 30 / 9403: 38$ & $012-1$ & 4.64 & 918.11 & 913.47 \\
\hline $07 / 30 / 9404: 39$ & $012-1$ & 4.59 & 918.11 & 913.52 \\
\hline $07 / 30 / 9405: 35$ & $012-1$ & 4.55 & 918.11 & 913.56 \\
\hline $07 / 30 / 9406: 41$ & $012-1$ & 4.51 & 918.11 & 913.60 \\
\hline $07 / 30 / 9407: 32$ & $012-1$ & 4.48 & 918.11 & 913.63 \\
\hline $07 / 30 / 9408: 30$ & $012-1$ & 4.45 & 918.11 & 913.66 \\
\hline $07 / 30 / 9409: 30$ & $012-1$ & 4.42 & 918.11 & 913.69 \\
\hline $07 / 30 / 9410: 30$ & $012-1$ & 4.39 & 918.11 & 913.72 \\
\hline $07 / 30 / 9411: 30$ & $012-1$ & 4.36 & 918.11 & 913.75 \\
\hline $07 / 30 / 9412: 29$ & $012-1$ & 4.34 & 918.11 & 913.77 \\
\hline $07 / 30 / 9413: 33$ & $012-1$ & 4.31 & 918.11 & 913.80 \\
\hline $07 / 30 / 9414: 31$ & $012-1$ & 4.30 & 918.11 & 913.81 \\
\hline $07 / 30 / 9416: 35$ & $012-1$ & 4.28 & 918.11 & 913.83 \\
\hline $07 / 30 / 9418: 38$ & $012-1$ & 4.27 & 918.11 & 913.84 \\
\hline $07 / 30 / 9420: 34$ & $012-1$ & 4.23 & 918.11 & 913.88 \\
\hline $07 / 30 / 9422: 34$ & $012-1$ & 4.19 & 918.11 & 913.92 \\
\hline $07 / 31 / 9400: 32$ & $012-1$ & 4.15 & 918.11 & 913.96 \\
\hline
\end{tabular}




\begin{tabular}{|c|c|c|c|c|}
\hline Date / Time & $\begin{array}{c}\text { Well / Sump } \\
\text { ID }\end{array}$ & $\begin{array}{l}\text { Depth To } \\
\text { Water }\end{array}$ & $\begin{array}{c}\text { Top of } \\
\text { Casing } \\
\text { Elevation }\end{array}$ & $\begin{array}{l}\text { Water } \\
\text { Elevation }\end{array}$ \\
\hline & & $(\mathrm{ft})$ & (msl) & (msl) \\
\hline $07 / 31 / 9402: 32$ & $012-1$ & 4.12 & 918.11 & 913.99 \\
\hline $07 / 31 / 9404: 30$ & $012-1$ & 4.09 & 918.11 & 914.02 \\
\hline $07 / 31 / 9406: 36$ & $012-1$ & 4.05 & 918.11 & 914.06 \\
\hline $07 / 31 / 94 \quad 10: 04$ & $012-1$ & 4.20 & 918.11 & 913.91 \\
\hline $07 / 31 / 9412: 04$ & $012-1$ & 4.64 & 918.11 & 913.47 \\
\hline $07 / 11 / 9409: 30$ & $012-2$ & 5.12 & 917.31 & 912.19 \\
\hline $07 / 15 / 9414: 00$ & $012-2$ & 5.12 & 917.31 & 912.19 \\
\hline $07 / 20 / 9409: 30$ & $012-2$ & 5.15 & 917.31 & 912.16 \\
\hline $07 / 29 / 9411: 50$ & $012-2$ & 4.50 & 917.31 & 912.81 \\
\hline $07 / 29 / 9413: 35$ & $012-2$ & 4.50 & 917.31 & 912.81 \\
\hline $07 / 29 / 9414: 31$ & $012-2$ & 4.49 & 917.31 & 912.82 \\
\hline $07 / 29 / 9415: 35$ & $012-2$ & 4.42 & 917.31 & 912.89 \\
\hline $07 / 29 / 94 \quad 16: 35$ & $012-2$ & 4.36 & 917.31 & 912.95 \\
\hline $07 / 29 / 9417: 34$ & $012-2$ & 4.30 & 917.31 & 913.01 \\
\hline $07 / 29 / 9418: 33$ & $012-2$ & 4.22 & 917.31 & 913.09 \\
\hline $07 / 29 / 9419: 30$ & $012-2$ & 4.16 & 917.31 & 913.15 \\
\hline $07 / 29 / 9420: 34$ & $012-2$ & 4.09 & 917.31 & 913.22 \\
\hline $07 / 29 / 9421: 33$ & $012-2$ & 4.04 & 917.31 & 913.27 \\
\hline $07 / 29 / 9422: 32$ & $012-2$ & 3.99 & 917.31 & 913.32 \\
\hline $07 / 29 / 9423: 36$ & $012-2$ & 3.93 & 917.31 & 913.38 \\
\hline $07 / 30 / 9400: 40$ & $012-2$ & 3.89 & 917.31 & 913.42 \\
\hline $07 / 30 / 9401: 35$ & $012-2$ & 3.85 & 917.31 & 913.46 \\
\hline $07 / 30 / 9402: 38$ & $012-2$ & 3.81 & 917.31 & 913.50 \\
\hline $07 / 30 / 9403: 40$ & $012-2$ & 3.76 & 917.31 & 913.55 \\
\hline $07 / 30 / 9404: 40$ & $012-2$ & 3.72 & 917.31 & 913.59 \\
\hline $07 / 30 / 9405: 38$ & $012-2$ & 3.69 & 917.31 & 913.62 \\
\hline $07 / 30 / 9406: 42$ & $012-2$ & 3.65 & 917.31 & 913.66 \\
\hline $07 / 30 / 9407: 34$ & $012-2$ & 3.63 & 917.31 & 913.68 \\
\hline $07 / 30 / 9408: 32$ & $012-2$ & 3.61 & 917.31 & 913.70 \\
\hline $07 / 30 / 9409: 31$ & $012-2$ & 3.58 & 917.31 & 913.73 \\
\hline $07 / 30 / 9410: 32$ & $012-2$ & 3.56 & 917.31 & 913.75 \\
\hline $07 / 30 / 9411: 31$ & $012-2$ & 3.53 & 917.31 & 913.78 \\
\hline $07 / 30 / 9412: 30$ & $012-2$ & 3.52 & 917.31 & 913.79 \\
\hline $07 / 30 / 9413: 34$ & $. .012-2$ & 3.50 & 917.31 & 913.81 \\
\hline $07 / 30 / 9414: 32$ & $012-2$ & 3.48 & 917.31 & 913.83 \\
\hline $07 / 30 / 9416: 37$ & $012-2$ & 3.45 & 917.31 & 913.86 \\
\hline $07 / 30 / 9418: 39$ & $012-2$ & 3.41 & 917.31 & 913.90 \\
\hline $07 / 30 / 9420: 36$ & $012-2$ & 3.38 & 917.31 & 913.93 \\
\hline $07 / 30 / 9422: 35$ & $012-2$ & 3.34 & 917.31 & 913.97 \\
\hline $07 / 31 / 9400: 34$ & $012-2$ & 3.31 & 917.31 & 914.00 \\
\hline $07 / 31 / 9402: 33$ & $012-2$ & 3.27 & 917.31 & 914.04 \\
\hline $07 / 31 / 9404: 31$ & $012-2$ & 3.24 & 917.31 & 914.07 \\
\hline $07 / 31 / 9406: 37$ & $012-2$ & 3.21 & 917.31 & 914.10 \\
\hline $07 / 31 / 9410: 05$ & $012-2$ & 3.26 & 917.31 & 914.05 \\
\hline $07 / 31 / 9412: 05$ & $012-2$ & 3.43 & 917.31 & 913.88 \\
\hline
\end{tabular}




\begin{tabular}{|c|c|c|c|c|}
\hline Date / Time & $\begin{array}{l}\text { Well / Sump } \\
\text { ID }\end{array}$ & $\begin{array}{l}\text { Depth To } \\
\text { Water }\end{array}$ & $\begin{array}{c}\text { Top Of } \\
\text { Casing } \\
\text { Elevation }\end{array}$ & $\begin{array}{l}\text { Water } \\
\text { Elevation }\end{array}$ \\
\hline & & $(\mathrm{ft})$ & (msl) & (msl) \\
\hline $07 / 31 / 9417: 49$ & $012-2$ & 3.98 & 917.31 & 913.33 \\
\hline $07 / 11 / 9409: 30$ & $012-3$ & 4.82 & 916.85 & 912.03 \\
\hline $07 / 15 / 9414: 00$ & $012-3$ & 5.04 & 916.85 & 911.81 \\
\hline $07 / 20 / 9409: 30$ & $012-3$ & 5.09 & 916.85 & 911.76 \\
\hline $07 / 29 / 9413: 00$ & $012-3$ & 4.49 & 916.85 & 912.36 \\
\hline $07 / 29 / 9413: 45$ & $012-3$ & 4.38 & 916.85 & 912.47 \\
\hline $07 / 29 / 9414: 34$ & $012-3$ & 4.27 & 916.85 & 912.58 \\
\hline $07 / 29 / 9415: 37$ & $012-3$ & 4.10 & 916.85 & 912.75 \\
\hline $07 / 29 / 9416: 38$ & $012-3$ & 4.07 & 916.85 & 912.78 \\
\hline $07 / 29 / 9417: 37$ & $012-3$ & 3.97 & 916.85 & 912.88 \\
\hline $07 / 29 / 9418: 36$ & $012-3$ & 3.91 & 916.85 & 912.94 \\
\hline $07 / 29 / 9419: 33$ & $012-3$ & 3.84 & 916.85 & 913.01 \\
\hline $07 / 29 / 9420: 36$ & $012-3$ & 3.77 & 916.85 & 913.08 \\
\hline $07 / 29 / 9421: 36$ & $012-3$ & 3.70 & 916.85 & 913.15 \\
\hline $07 / 29 / 9422: 34$ & $012-3$ & 3.65 & 916.85 & 913.20 \\
\hline $07 / 29 / 9423: 40$ & $012-3$ & 3.58 & 916.85 & 913.27 \\
\hline $07 / 30 / 9400: 45$ & $012-3$ & 3.53 & 916.85 & 913.32 \\
\hline $07 / 30 / 9401: 39$ & $012-3$ & 3.50 & 916.85 & 913.35 \\
\hline $07 / 30 / 9402: 43$ & $012-3$ & 3.50 & 916.85 & 913.35 \\
\hline $07 / 30 / 9403: 45$ & $012-3$ & 3.40 & 916.85 & 913.45 \\
\hline $07 / 30 / 9404: 43$ & $012-3$ & 3.38 & 916.85 & 913.47 \\
\hline $07 / 30 / 9405: 43$ & $012-3$ & 3.32 & 916.85 & 913.53 \\
\hline $07 / 30 / 9406: 45$ & $012-3$ & 3.28 & 916.85 & 913.57 \\
\hline $07 / 30 / 9407: 38$ & $012-3$ & 3.26 & 916.85 & 913.59 \\
\hline $07 / 30 / 9408: 35$ & $012-3$ & 3.22 & 916.85 & 913.63 \\
\hline $07 / 30 / 9409: 36$ & $012-3$ & 3.20 & 916.85 & 913.65 \\
\hline $07 / 30 / 94 \quad 10: 35$ & $012-3$ & 3.17 & 916.85 & 913.68 \\
\hline $07 / 30 / 9411: 36$ & $012-3$ & 3.14 & 916.85 & 913.71 \\
\hline $07 / 30 / 9412: 34$ & $012-3$ & 3.12 & 916.85 & 913.73 \\
\hline $07 / 30 / 9413: 39$ & $012-3$ & 3.10 & 916.85 & 913.75 \\
\hline $07 / 30 / 9414: 37$ & $012-3$ & 3.08 & 916.85 & 913.77 \\
\hline $07 / 30 / 9416: 40$ & $012-3$ & 3.06 & 916.85 & 913.79 \\
\hline $07 / 30 / 9418: 42$ & $012-3$ & 3.03 & 916.85 & 913.82 \\
\hline $07 / 30 / 9420: 39$ & $012-3$ & 2.99 & 916.85 & 913.86 \\
\hline $07 / 30 / 9422: 38$ & $012-3$ & 2.95 & 916.85 & 913.90 \\
\hline $07 / 31 / 9400: 40$ & $012-3$ & 2.91 & 916.85 & 913.94 \\
\hline $07 / 31 / 9402: 37$ & $012-3$ & 2.88 & 916.85 & 913.97 \\
\hline $07 / 31 / 9404: 35$ & $012-3$ & 2.85 & 916.85 & 914.00 \\
\hline $07 / 31 / 9406: 41$ & $012-3$ & 2.82 & 916.85 & 914.03 \\
\hline $07 / 31 / 9410: 08$ & $012-3$ & 2.98 & 916.85 & 913.87 \\
\hline $07 / 31 / 9412: 09$ & $012-3$ & 3.25 & 916.85 & 913.60 \\
\hline $07 / 31 / 9417: 52$ & $012-3$ & 3.95 & 916.85 & 912.90 \\
\hline $07 / 11 / 9409: 30$ & $012-4$ & 1.87 & 914.54 & 912.67 \\
\hline $07 / 15 / 9414: 00$ & $012-4$ & 1.87 & 914.54 & 912.67 \\
\hline $07 / 20 / 9409: 30$ & $012-4$ & 1.84 & 914.54 & 912.70 \\
\hline
\end{tabular}




\begin{tabular}{|c|c|c|c|c|}
\hline Date / Time & $\begin{array}{c}\text { Well / Sump } \\
\text { ID }\end{array}$ & $\begin{array}{l}\text { Depth To } \\
\text { Water }\end{array}$ & $\begin{array}{c}\text { Top Of } \\
\text { Casing } \\
\text { Elevation }\end{array}$ & $\begin{array}{c}\text { Water } \\
\text { Elevation }\end{array}$ \\
\hline & & (ft) & (msl) & (msl) \\
\hline 07/29/94 12:00 & $012-4$ & 1.51 & 914.54 & 913.03 \\
\hline $07 / 29 / 9413: 50$ & $012-4$ & 1.44 & 915.54 & 914.10 \\
\hline $07 / 29 / 9414: 35$ & $012-4$ & 1.41 & 914.54 & 913.13 \\
\hline $07 / 29 / 9415: 39$ & $012-4$ & 1.38 & 914.54 & 913.16 \\
\hline $07 / 29 / 9416: 39$ & $012-4$ & 1.35 & 914.54 & 913.19 \\
\hline $07 / 29 / 9417: 39$ & $012-4$ & 1.29 & 914.54 & 913.25 \\
\hline $07 / 29 / 9418: 37$ & $012-4$ & 1.24 & 914.54 & 913.30 \\
\hline $07 / 29 / 9419: 35$ & $012-4$ & 1.19 & 914.54 & 913.35 \\
\hline $07 / 29 / 9420: 37$ & $012-4$ & 1.13 & 914.54 & 913.41 \\
\hline $07 / 29 / 9421: 37$ & $012-4$ & 1.09 & 914.54 & 913.45 \\
\hline $07 / 29 / 9422: 35$ & $012-4$ & 1.05 & 914.54 & 913.49 \\
\hline $07 / 29 / 9423: 43$ & $012-4$ & 1.01 & 914.54 & 913.53 \\
\hline $07 / 30 / 9400: 47$ & $012-4$ & 0.99 & 914.54 & 913.55 \\
\hline $07 / 30 / 9401: 41$ & $012-4$ & 0.96 & 914.54 & 913.58 \\
\hline $07 / 30 / 9402: 46$ & $012-4$ & 0.91 & 914.54 & 913.63 \\
\hline $07 / 30 / 9403: 50$ & $012-4$ & 0.88 & 914.54 & 913.66 \\
\hline $07 / 30 / 9404: 45$ & $012-4$ & 0.86 & 914.54 & 913.68 \\
\hline $07 / 30 / 9405: 45$ & $012-4$ & 0.84 & 914.54 & 913.70 \\
\hline $07 / 30 / 9406: 46$ & $012-4$ & 0.81 & 914.54 & 913.73 \\
\hline $07 / 30 / 9407: 39$ & $012-4$ & 0.80 & 914.54 & 913.74 \\
\hline $07 / 30 / 9408: 37$ & $012-4$ & 0.89 & 914.54 & 913.65 \\
\hline $07 / 30 / 9409: 37$ & $012-4$ & 0.88 & 914.54 & 913.66 \\
\hline $07 / 30 / 9410: 36$ & $012-4$ & 0.86 & 914.54 & 913.68 \\
\hline $07 / 30 / 9411: 37$ & $012-4$ & 0.84 & 914.54 & 913.70 \\
\hline $07 / 30 / 9412: 35$ & $012-4$ & 0.81 & 914.54 & 913.73 \\
\hline $07 / 30 / 9413: 41$ & $012-4$ & 0.78 & 914.54 & 913.76 \\
\hline $07 / 30 / 9414: 38$ & $012-4$ & 0.75 & 914.54 & 913.79 \\
\hline $07 / 30 / 9416: 40$ & $012-4$ & 0.65 & 914.54 & 913.89 \\
\hline $07 / 30 / 9418: 44$ & $012-4$ & 0.58 & 914.54 & 913.96 \\
\hline $07 / 30 / 9420: 41$ & $012-4$ & 0.58 & 914.54 & 913.96 \\
\hline $07 / 30 / 9422: 40$ & $012-4$ & 0.51 & 914.54 & 914.03 \\
\hline $07 / 31 / 9400: 42$ & $012-4$ & 0.50 & 914.54 & 914.04 \\
\hline $07 / 31 / 9402: 38$ & $012-4$ & 0.48 & 914.54 & 914.06 \\
\hline $07 / 31 / 9404: 38$ & $012-4$ & 0.44 & 914.54 & 914.10 \\
\hline $07 / 31 / 9406: 42$ & $012-4$ & 0.42 & 914.54 & 914.12 \\
\hline $07 / 31 / 9410: 09$ & $012-4$ & 0.56 & 914.54 & 913.98 \\
\hline $07 / 31 / 9412: 10$ & $012-4$ & 0.66 & 914.54 & 913.88 \\
\hline $07 / 31 / 9417: 53$ & $012-4$ & 0.97 & 914.54 & 913.57 \\
\hline
\end{tabular}




\section{DISTRIBUTION}

1. L. V. Asplund

2. M. A. Bogle

3. K. R. Henke

4. W. K. Jago

5. J. A. Johnston

6. H. L. King

7. A. K. Lee

8-9. D. M. Matteo

10. H. C. Newsom

11-12. P. T. Owen

13. G. R. Southworth

14. R.R. Turner

15. C. S. Walker

16. D. B. Watson

17. Central Research Library

18. ER Central Doc. Mgmt. Center-RC

19. Office of Scientific and Technical Information, P.O. Box 62, Oak Ridge, TN 37831 